\title{
Pathogenic, Morphological, and Phylogenetic Characterization of Fusarium solani f. sp. cucurbitae Isolates From Cucurbits in Almería Province, Spain
}

\author{
Ana Pérez-Hernández, ${ }^{1, \dagger}$ Liliana O. Rocha, ${ }^{2}$ Elena Porcel-Rodríguez, ${ }^{1}$ Brett A. Summerell, ${ }^{3}$ Edward C. Y. Liew, ${ }^{3}$ and \\ Julio M. Gómez-Vázquez ${ }^{1}$ \\ ${ }^{1}$ IFAPA Centro La Mojonera, La Mojonera, Almería 04745, Spain \\ ${ }^{2}$ Departamento de Ciencia de los Alimentos, Universidade Estadual de Campinas, Campinas, SP 13.083-862, Brazil \\ ${ }^{3}$ The Royal Botanic Gardens and Domain Trust, Sydney, NSW 2000, Australia
}

\begin{abstract}
Fusarium solani f. sp. cucurbitae (syn. Neocosmosporum cucurbitae) is one of the most devastating soilborne pathogens affecting the production of cucurbits worldwide. Since its first detection in Almería Province in Spain in the spring of 2007, it has become one of the main soilborne pathogens affecting zucchini production. It has also been reported on melon, watermelon, and squash rootstocks in Spain, representing a high risk of dissemination in the area. The objectives of this study were to investigate the incidence and distribution of this disease in southeastern Spain and characterize isolates collected over 5 years. These strains were characterized on the basis of greenhouse

aggressive on zucchini plants, causing a high mortality rate a few weeks after inoculation. The rest of the cucurbit hosts showed differential susceptibility to the pathogen, with cucumber being the least susceptible. Plants belonging to other families remained asymptomatic. Morphological characterization revealed the formation of verticilate monophialides and chlamydospores forming long chains, characteristics not described for this forma specialis. Phylogenetic studies of both the individual loci and combined datasets revealed that all pathogenic isolates clustered together with strong monophyletic support, nested within clade 3 in the $F$. solani species complex.
\end{abstract} aggressiveness assays on a range of cucurbit hosts, morphological characteristics, and elongation factor 1- $\alpha$ and RNA polymerase II second largest subunit phylogenies. All pathogenic isolates were highly

Keywords: disease development and spread, epidemiology, fungi, pathogen diversity

Zucchini (Cucurbita pepo L.) is intensively cropped in the province of Almería, the main vegetable production area in Spain. In 2016, zucchini was produced on 11,081 ha in Spain, of which 7,490 ha were for greenhouse production in Almería, producing 434,195 metric tons of this crop. This production accounts for $74.7 \%$ of the total production in Spain, making it one of the most economically important crops for this region (MAPA 2017).

In 2007, a new fungal disease of zucchini was detected in the province of Almería. The first symptom observed was a dark green coloration of the younger leaves followed by wilt, crown rot, and eventual plant death. The causal agent was Fusarium solani (Mart) Sacc f. sp. cucurbitae W. C. Snyder and H. N. Hansen (Gómez et al. 2008), which is host specific to cucurbits (Boughalleb et al. 2007; Messiaen et al. 1995; Paternotte 1987). This pathogen has been reported worldwide, causing disease in field production in pumpkin (Elmer et al. 2007), muskmelon (Champaco et al. 1993), cucumber (Bourbos

${ }^{\dagger}$ Corresponding author: A. Pérez-Hernández; anaperezh@gmail.com

Funding: A. Pérez-Hernández was supported by a predoctoral fellowship financed by the INIA, Spain (Ministerio de Agricultura y Pesca, Alimentación y Medio Ambiente grant number RTA2010-00044-00-00) and granted with a scholarship for a 3-month stay at the Royal Botanic Gardens and Domain Trust of Sydney, Australia (RBG). We thank the RBG for the financial support for conducting the phylogenetic studies.

*The $\boldsymbol{e}$-Xtra logo stands for "electronic extra" and indicates that three supplementary figures are published online.

The author(s) declare no conflict of interest.

Accepted for publication 6 December 2019.

This article is in the public domain and not copyrightable. It may be freely reprinted with customary crediting of the source. The American Phytopathological Society, 2020. et al. 1997), watermelon, and rootstock hybrids of Cucurbita maxima $\times$ Cucurbita moschata (Armengol et al. 2000) among other hosts.

In Almería, zucchini crops have been considered for years to be highly resistant to soilborne fungal diseases. Until this study, aside from $F$. solani f. sp. cucurbitae, only Phytophthora capsici Leonian has been detected as the causal agent of a soilborne disease in adult plants in this area (Gómez et al. 2013). Furthermore, since its detection, Fusarium crown, foot, and fruit rot of zucchini has been spreading to other cucurbits, such as melon (Gómez et al. 2014) and watermelon (Porcel 2013), becoming an important threat to the cucurbit production in this region.

Several methods can be used for the control of Fusarium crown rot, such as fungicide applications with prochloraz, carbendazim, and thiophanate-methyl; crop rotation with noncucurbits for at least 2 years; or soil solarization or biosolarization (Pérez-Hernández et al. 2017).

In the decades since 2000, molecular tools have revolutionized the understanding of fungal taxonomy, including that of the genus Fusarium. Phylogenetic studies have demonstrated that several species actually correspond to species complexes composed of different morphologically indistinguishable cryptic species. $F$. solani, known as the $F$. solani species complex (FSSC), comprises three major clades encompassing $>60$ phylogenetic species (Nalim et al. 2011; O'Donnell 2000; O'Donnell et al. 2008; Short et al. 2013; Zhang et al. 2006). Members of clades 1 and 2 are known exclusively from diseased or dead plants, whereas members of clade 3 are frequently isolated from soil and as saprotrophs in other environments, causing diseases in immunocompromised humans (Zhang et al. 2006). In addition, clades 1 and 2 are composed of isolates limited to specific geographical origins (New Zealand and South America, respectively), whereas clade 3 includes most of the commonly encountered FSSC isolates associated with plant diseases and soil, with a cosmopolitan distribution (O'Donnell 2000). Lombard et al. (2015) proposed that the FSSC be redefined as Neocosmospora species based on morphology of the group, especially the sexual structures, and DNA phylogenetic placement. Geiser et al. (2004) argued that such a change was unnecessary, maintaining that the taxonomy better 
serves the community needs, especially with respect to plant biosecurity and human health, by retaining the species complex within the genus Fusarium. Additionally, Summerell (2019) argued for the retention of the genus Fusarium for the species complex until such a time that there is consensus of view. Consequently, we have retained the use of the genus Fusarium for these fungi in this study.

Sandoval-Denis et al. (2019) have monographed the FSSC (as the genus Neocosmospora) and described $F$. solani f. sp. cucurbitae as Neocosmospora cucurbitae based on morphology and DNA phylogeny. Based on the available data, we refer to the fungus as $F$. solani f. sp. cucurbitae throughout this paper.

F. solani f. sp. cucurbitae (syn. N. cucurbitae) was first described by Snyder and Hansen (1941) in 1941 as the causal agent of crown and foot rot of cucurbits. In 1961, Tousson and Snyder (1961) divided this forma specialis into two races on the basis of their ability to produce crown and foot rot in cucurbit plants, designated as F. solani f. sp. cucurbitae race 1, or only able to produce fruit rot, designated as F. solani f. sp. cucurbitae race 2. In 1973, Matuo and Snyder (1973) conducted fertility crosses between the different forma speciales described within $F$. solani, demonstrating that both races correspond to different biological species assigned to different mating populations MP-I and MP-V, respectively. Some decades later, a comprehensive phylogenetic study (O'Donnell 2000) revealed that both races of $F$. solani $\mathrm{f}$. sp. cucurbitae were polyphyletic, therefore representing two distinct phylogenetic species. Several years later, given the large amount of phylogenetic species lacking proper descriptions and Latin binomials in addition to the need to facilitate better communication, a haplotype nomenclatural system was introduced in which each phylogenetic species received a numerical identifier, with unique sequence types within species designated by lower case letters (Chang et al. 2006; O'Donnell et al. 2008). In this study, race 1 was assigned to the phylogenetic species FSSC 10, with two haplotypes FSSC 10a and FSSC 10b, whereas race 2 was assigned to FSSC 1. Mehl and Epstein (2007) and Zhang et al. (2006) demonstrated that race 2 was conspecific with the phylogenetic species FSSC 1, which was the most common phylogenetic species isolated in hospital environments and one of the predominant species in the 2005 to 2006 outbreaks of mycotic keratitis in the United States and Southeast Asia associated with contact lens wear (Chang et al. 2006; Khor et al. 2006). Additional studies have confirmed this hypothesis, and in 2013, the former forma specialis was elevated to the species rank, Fusarium petroliphilum stat. nov. (Short et al. 2013).

In this context, the aim of this study was to investigate the incidence and distribution of Fusarium crown and foot rot of cucurbits in Almería Province and characterize a collection of $F$. solani f. sp. cucurbitae isolates obtained over the years from different hosts. These isolates were analyzed on the basis of their pathogenicity to zucchini and other cucurbit hosts; a detailed description of their morphological characteristics; and their elongation factor 1- $\alpha$ (EF1- $\alpha)$ and RNA polymerase II second largest subunit $(R P B 2)$ phylogenetic relationships within the FSSC.

\section{Materials and Methods}

Disease survey. To assess the incidence and geographical distribution of Fusarium crown and foot rot of zucchini in the province of Almería, isolates were collected in zucchini commercial greenhouses situated in different growing areas. Crops with plants showing foot rot, wilt, or death were visited in collaboration with the Production and Plant Health Laboratory, Almería, and agricultural technicians. In addition, five cucumber greenhouses, one watermelon greenhouse, and one melon greenhouse with plants showing similar disease symptoms were included in this survey.

In each of the greenhouses visited, the percentage of plants showing any of the abovementioned symptoms was estimated, and plant samples were collected to diagnose the causal agent of the disease and obtain a collection of isolates.

Collection of isolates. Basal stem samples were surface disinfected, placed on Komada medium (Komada 1975), potato dextrose agar (PDA) medium (Rapilly 1968), and P5ARP (Jeffers and Martin 1986); and incubated at $25^{\circ} \mathrm{C}$ for 2 to 3 days. Colonies were obtained and subcultured on PDA or lima bean agar (Calvert et al. 1960). In addition, to detect possible chlamydospores or perithecia of Chalara elegans or Monosporascus cannonballus, roots were observed under a stereoscopic microscope. The isolates classified as $F$. solani according to their morphological characteristics were maintained as single-spore cultures in the IFAPA (Instituto de Investigación y Formación Agraria y, Pesquera de Andalucía) Centro La Mojonera. Among a collection of a total of 83 Fusarium spp. isolates, 22 of them were selected for this study, and the isolate PCl-711 was deposited with the accession number CECT20831 in the Colección Española de Cultivos Tipo, Parque Científico de la Universidad de Valencia, Paterna, Spain.

Production of pathogen inoculum. For the pathogenicity tests, cultures of each isolate were grown on 90-mm PDA plates and incubated under indirect natural light at $25^{\circ} \mathrm{C}$ between 15 and 20 days until the plates were completely colonized. Conidial suspensions were then prepared by scraping the surface of the plates with a sterile loop and recovered by washing the plates with autoclaved water. The inoculum was then filtered through a $0.5-\mathrm{mm}$ mesh to remove large portions of mycelia and adjusted with a hemocytometer to an approximate concentration of $1.5 \times 10^{3}$ conidia $\mathrm{ml}^{-1}$. Fifty milliliters of inoculum was poured around the stem base of each plant.

Plant growth and maintenance. The first pathogenicity trial of the fungus on various horticultural crops was conducted in an $80-\mathrm{m}^{2}$, multispan polymethyl methacrylate-covered greenhouse equipped with ridge and side windows in a semicontrolled environment with a cooling system as well as automated climate control and fertigation. The second pathogenicity trial on various horticultural crops was conducted in a $970-\mathrm{m}^{2}$, multispan polyethylene-covered greenhouse to maintain the plants for a longer period of time along with the pathogenicity trials on zucchini plants. The greenhouse was equipped with ridge and side windows as well as automated climate control and fertigation. All greenhouses were located in the IFAPA Centro La Mojonera, Almería Province, Spain ( $\left.36^{\circ} 47^{\prime} 17^{\prime \prime},-2^{\circ} 42^{\prime} 14^{\prime \prime}\right)$. Fertigation was managed with a programmable system based on the leaching fraction, which was maintained close to $20 \%$. Temperature for all crops was measured inside the bags of perlite and in the greenhouse environment above the plant canopies with P-108 temperature probes for 10-min intervals and recorded with a Campbell CR10X datalogger (Campbell Scientific, Inc., Logan, UT).

Pathogenicity trials on zucchini plants and fruit. The pathogenicity of the isolates used in this study was tested on both zucchini plants and fruit. To evaluate the pathogenicity on zucchini plants, two trials were conducted: one commenced during the third week of February 2012 (first trial), and the other commenced during the third week of May 2012 (second trial). The experiments were arranged as a randomized complete block design with four replicates. Each experimental unit within a block consisted of four bags of perlite with 3 plants per bag, totaling 48 plants per isolate in each trial. An uninoculated control was included for each block. Seeds of the cultivar Cónsul (Seminis Vegetable Seeds, St. Louis, MO) were sown in the bags, and the plants were inoculated at the two- to three-true leaf stage as previously described. Plants were monitored twice a week for the presence of disease symptoms. Disease incidence (DI) and mortality (M) were calculated as the percentages of symptomatic plants per isolate at the end of the experiment. In addition, disease severity was assessed by using a 0 to 2 rating scale, where $0=$ plant without symptoms, 1 = aerial disease symptoms, and $2=$ plant death. These data were plotted against time for each experiment, and the development of the disease was evaluated by calculating the area under the disease progress curve (AUDPC) using the trapezoidal method (Madden et al. 2007). The relative area under the disease progress curve (RAUDPC) was calculated as the proportion of the maximum possible AUDPC. Plants were maintained in the greenhouse over periods of 65 and 53 days for the first and second trials, respectively. At the end of the experiments, $10 \%$ of the symptomatic plants were randomly selected for pathogen reisolation to fulfill Koch's postulates.

To evaluate the pathogenicity of $F$. solani isolates on zucchini fruit, two consecutive trials were conducted. The experiments were 
arranged in a randomized complete block design with four replicates. Each experimental unit within a block consisted of one zucchini fruit with three wounds. Multiple fruits of approximately $200 \mathrm{~g}$ were surface disinfected by spraying with $70 \%$ ethanol on the surface and allowed to dry. Wounds of a depth of approximately $5 \mathrm{~mm}$ were made in the fruit surface with a cork borer; 7-mm PDA plugs, excised from the actively growing margins of 5-day-old synthetic nutrientpoor agar (SNA) cultures of each isolate, were placed mycelium side down into the wounds. Three wounds per fruit and four fruits were inoculated with each isolate. Two fruits per block were inoculated with uncolonized PDA plugs to serve as negative controls. To maintain a humid environment, the fruits were placed on shelves and covered with unsealed plastic bags to allow air flow. Fruits were incubated in the laboratory at approximately $25^{\circ} \mathrm{C}$. After 7 days of incubation, the diameter of the lesion produced on the fruit was obtained from an average of two perpendicular measures after subtracting the diameter of the wound.

Pathogenicity on other horticultural crops. After verifying the pathogenicity of 21 Fusarium isolates on both zucchini plants and fruit, two representative isolates were selected to study the pathogenicity of $F$. solani $\mathrm{f}$. sp. cucurbitae to other horticultural crops. Two trials were conducted: one commenced during the first week of April 2013 (first trial), and the other commenced during the second week of April 2014 (second trial). The experiments were arranged in a factorial design in three blocks, with each block comprising six plants. Factors studied were inoculation with the isolate PCl-511 obtained from zucchini, inoculation with the isolate PCl-1621 obtained from watermelon, and noninoculated controls; the following horticultural species were evaluated: melon (Cucumis melo) cultivar Amarillo Canario Jardiver; watermelon (Citrullus lanatus) cultivar Mariola; tomato (Solanum lycopersici) cultivar Pasadena; eggplant (Solanum melongena) cultivar Alegría; pea (Pisum sativum) cultivar Altesse; lettuce (Lactuca sativa) cultivar Romana Jardiver (Ramiro Arnedo S.A., Calahorra, Spain); cucumber cultivars Borja (Enza Zaden Beheer, B.V., Enkhuizen, the Netherlands), Marketmore, and Pepinillo Jardiver (Ramiro Arnedo S.A.); zucchini (Cucurbita pepo) cultivar Cónsul (Seminis Vegetable Seeds, Woodland, CA); squash rootstock (Cucurbita maxima $\times$ Cucurbita moschata) cultivars RS-841 (Akira Seeds S.L., Sant Boi de Llobregat, Spain), Hércules, and Titán (Ramiro Arnedo S.A.); pepper (Capsicum annuum) cultivar Airen (Syngenta Seeds Inc., Boise, ID); snow pea (Pisum sativum sp. arvense) cultivar Capuchino (Semillas Batlle S.A., Molins de Rei, Spain); and green bean (Phaseolus vulgaris) cultivar Emerite (Vilmorin, La Ménitré, France). In the first trial, plants were sown in 1-liter pots with vermiculite and inoculated when the cotyledons were completely opened as previously described. In the second trial, seeds were sown in 32-liter perlite bags to maintain the plants for a longer period of time. Plants were monitored twice a week for the presence of disease symptoms, and the parameters DI, M, and RAUDPC were calculated per treatment as previously described. At the end of the experiments, $10 \%$ of the symptomatic plants per species were randomly selected for pathogen reisolation.

Determination of mycelial growth rates and morphological characteristics. Cardinal growth rates were determined by measuring the in vitro growth of four representative isolates (PCl-341, PCl-511, PCl-731, and PCl-1621) at different temperatures. Mycelial plugs with a diameter of $7 \mathrm{~mm}$ were excised from the actively growing margins of 4-day-old PDA cultures and placed mycelium side down in the center of 90-mm PDA plates, sealed with laboratory film, and incubated for 6 days in complete darkness at each of the following temperatures: $8,11,14,17,20,23,26,29,32$, and $35^{\circ} \mathrm{C}$. Mycelial growth data were obtained by calculating the average of two perpendicular measures of the colony diameter after 6 days of growth. Rates were calculated as mean values per day. Four repetitions of each temperature-isolate were included; this experiment was performed twice.

Morphological characteristics of the isolates were examined based on the criteria of Leslie and Summerell (2006). Single-spore isolates were grown using SNA (Nirenberg 1976) for 10 days at $25^{\circ} \mathrm{C}$, and subsequently, 7-mm plugs from actively growing edges of each culture were subcultured in plates with PDA, carnation leaf-piece agar (CLA) (Leslie and Summerell 2006), and SNA in 90-mm plastic petri dishes. Six repetitions per isolate were included, and the plates were incubated for 10 days at $25^{\circ} \mathrm{C}$ under indirect natural light or continuous Blacklight Blue (F40 BLB) fluorescent light. Colony color and morphology together with the morphology and type of conidiogenous cells were recorded from cultures grown on PDA plates under natural indirect light. The morphology, size, and shape of 30 randomly selected microconidia formed on SNA plates and the presence or absence and shape of 30 chlamydospores were determined under an Olympus BX41 microscope and a ColorView IIIu camera (Olympus Soft Imaging Solutions GmbH, Münster, Germany). The production of sporodochia on CLA was induced on subcultures incubated at $25^{\circ} \mathrm{C}$ under continuous BLB light and checked within 15 days of incubation. The length and width of 30 randomly selected macroconidia of each septation class on CLA and the number of septa were measured and recorded. The reported measurements consisted of the minimum and maximum values in brackets as well as the mean values plus and minus the standard deviation.

Genomic DNA extraction, PCR amplification, and sequencing. Fusarium cultures were grown on PDA for 5 days. Genomic DNA was extracted using the E.Z.N.A. Fungal DNA Mini Kit (Omega Bio-Tek, Norcross, GA) according to the manufacturer's instructions. The PCR amplifications of the isolates were performed for part of the translation $E F 1-\alpha$ using the primers EF1 (5'-ATGGGTAAG $\left.\mathrm{GA}(\mathrm{A} / \mathrm{G}) \mathrm{GACAAGAC}-3^{\prime}\right)$ and EF2 (5'-GGA(G/A)GTAC CAGT(G/C)ATCATGTT-3') (Carbone and Kohn 1999) and RPB2 using the primers $5 f 2\left(5^{\prime}\right.$-GGGGWGAYCAGAAGAAGGC-3') (Reeb et al. 2004) and 7cr (5'-CCCATRGCTTGTYYRCCCAT$3^{\prime}$ ) (Liu et al. 1999). Conditions for amplification for the $E F 1-\alpha$ gene region were an initial denaturation step of $3 \mathrm{~min}$ at $95^{\circ} \mathrm{C}$ followed by 30 cycles of denaturation $\left(95^{\circ} \mathrm{C}\right.$ for $\left.30 \mathrm{~s}\right)$, annealing $\left(53^{\circ} \mathrm{C}\right.$ for $\left.30 \mathrm{~s}\right)$, and elongation $\left(72^{\circ} \mathrm{C}\right.$ for $\left.45 \mathrm{~s}\right)$. The final elongation step was conducted at $72^{\circ} \mathrm{C}$ for $7 \mathrm{~min}$. For the $R P B 2$ loci, amplification consisted of 5 cycles of $45 \mathrm{~s}$ at $94^{\circ} \mathrm{C}, 45 \mathrm{~s}$ at $60^{\circ} \mathrm{C}$, and $2 \mathrm{~min}$ at $72^{\circ} \mathrm{C} ; 5$ cycles of $45 \mathrm{~s}$ at $94^{\circ} \mathrm{C}, 45 \mathrm{~s}$ at $58^{\circ} \mathrm{C}$, and $2 \mathrm{~min}$ at $72^{\circ} \mathrm{C}$; and 30 cycles of $45 \mathrm{~s}$ at $94^{\circ} \mathrm{C}, 45 \mathrm{~s}$ at $54^{\circ} \mathrm{C}$, and $2 \mathrm{~min}$ at $72^{\circ} \mathrm{C}$ (Woudenberg et al. 2013). The PCR amplicons were sequenced in both directions at the Ramaciotti Centre for Gene Function Analysis at the University of New South Wales, Australia, or by the Sequencing Service, Instituto de Biología Molecular y Celular de Plantas, Valencia, Spain.

Phylogenetic analyses. Sequences obtained were edited manually in Geneious software v.5.3.6 (Drummond et al. 2011), and their classification as the genus Fusarium was confirmed through the BLAST in the NCBI (https://blast.ncbi.nlm.nih.gov/Blast.cgi ) and the Fusarium-ID v. 1.0 database (Geiser et al. 2004). The sequences were aligned with reference sequences from the FSSC obtained from GenBank (Table 1) with ClustalW v.1.83 plug in within Geneious. The alignments were edited, and polymorphisms were confirmed by reexamining the chromatograms. Sequences generated in this study were deposited in GenBank (Table 2). Phylogenetic analyses were performed using PAUP 4.0b10 (Swofford 2002) on the single and combined $E F 1-\alpha$ and $R P B 2$ datasets. Unweighted parsimony analysis was conducted using the heuristic search option with 1,000 random addition sequences and tree bisection reconnection branch swapping. Gaps were treated as missing data. The consistency index (CI) and the retention index (RI) were calculated to indicate the amount of homoplasy present. Clade stability was assessed via maximum parsimony bootstrap proportions in PAUP 4.0b10 using 1,000 heuristic search replications with random sequence addition. The EF1- $\alpha$ and RPB2 datasets were rooted with Fusarium thapsinum NRRL22045. Phylogenetic trees were visualized and edited using FigTree v.1.4 (Rambaut 2013).

Statistical analyses. Kruskal-Wallis nonparametric analysis of variance (ANOVA) tests were conducted for each of the experiments, of which the DI expressed as the percentage of symptomatic plants per treatment, M, and RAUDPC were analyzed with Statistix 9.0 (Tallahassee, FL) owing to data nonnormality and variance heterogeneity. The different repetitions of the experiments were 
included in the model and assayed for differences. In cases where ANOVA revealed no significant differences between experiments, data were pooled prior to analyses. In all cases, if the ANOVA results were significant for the main effects, treatment means were compared using all-pairwise comparison tests $(P \leq$ $0.05)$.

\section{Results}

Disease survey. A total of 26 zucchini greenhouses, 5 cucumber greenhouses, 1 melon greenhouse, and 1 watermelon greenhouse with diseased plants were surveyed where symptoms similar to those caused by $F$. solani f. sp. cucurbitae were observed, mainly leaf wilt, brown rot lesions at the base of the stem near the soil level, and plant death (Supplementary Fig. S1). In addition, 25 zucchini samples from the Production and Plant Health Laboratory with similar disease symptoms were included in this study. $F$. solani was present in $92.3 \%$ of the zucchini greenhouses surveyed and $100 \%$ of the zucchini samples received by the Plant Health Laboratory of Almería. Several of the affected greenhouses were located in the municipality of Las Norias de Daza, where the disease was first observed in zucchini (Gómez et al. 2008). In addition, the DI was observed throughout the province in at least five different municipalities. The DI among the different greenhouses visited was variable. In some greenhouses, the disease affected a small number of plants distributed in one or few rows. In most of the cases, the percentage of affected plants ranged between 5 and $30 \%$. In two greenhouses, between 50 and $60 \%$ of the plants showed crown and foot rot symptoms. In most of the cases, the disease was observed in spring and summer crops, but in some cases, it was detected in autumn crops in greenhouses that had been soil disinfested during summer, a common practice

Table 1. Reference strains obtained from the NCBI GenBank database used in the phylogenetic analysis of Fusarium solani f. sp. cucurbitae isolates

\begin{tabular}{|c|c|c|c|c|c|}
\hline \multirow[b]{2}{*}{ Species } & \multirow[b]{2}{*}{ Collection ${ }^{y}$} & \multicolumn{2}{|c|}{ GenBank accession number ${ }^{\mathbf{Z}}$} & \multirow[b]{2}{*}{ Host } & \multirow[b]{2}{*}{ Origin } \\
\hline & & $E F 1-\alpha$ & $R P B 2$ & & \\
\hline Fusarium thapsinum (outgroup) & NRRL22045 & AF160270 & JX171600 & Sorghum bicolor & South Africa \\
\hline Fusarium virguliforme & NRRL22825 & AF178357 & GU170615 & Glycine $\max$ & United States \\
\hline Fusarium tucumaniae & NRRL31096 & GU170600 & EU329557 & Glycine max & Argentina \\
\hline Fusarium striatum & NRRL22101 & AF178333 & EU329490 & Gossypium sp. & Panama \\
\hline F. solani sensu stricto & NRRL25388 & DQ246857 & EU329535 & Human eye & India \\
\hline F. solani sensu stricto & NRRL32737 & DQ247056 & EU329606 & Human eye & United States \\
\hline F. solani $\mathrm{f}$. sp. xanthoxyli & NRRL22163 & AF178328 & EU329496 & Xanthoxylum piperitum & Japan \\
\hline F. solani f. sp. robiniae & NRRL22586 & AF178353 & EU329516 & Robinea pseudoacacia & United States \\
\hline F. solani f. sp. robiniae & NRRL22161 & AF178330 & EU329494 & Robinea pseudoacacia & Japan \\
\hline F. solani f. sp. robiniae & NRRL22162 & DQ247599 & EU329495 & Robinea pseudoacacia & Japan \\
\hline F. solani f. sp. piperis & NRRL22570 & AF178360 & EU329513 & Piper nigrum & Brazil \\
\hline F. solani f. sp. mori & NRRL22230 & AF178358 & EU329499 & Morus alba & Japan \\
\hline F. solani f. sp. mori & NRRL22157 & AF178359 & EU329493 & Morus alba & Japan \\
\hline F. solani f. sp. cucurbitae & NRRL22098 & AF178327 & EU329489 & Cucurbita ssp. & United States \\
\hline F. solani f. sp. cucurbitae & NRRL22153 & AF178346 & EU329492 & Cucurbita spp. & United States \\
\hline F. solani f. sp. batatas & NRRL22400 & AF178343 & EU329509 & Ipomoea batatas & United States \\
\hline F. solani $9 \mathrm{a}$ & NRRL32755 & DQ247072 & EU329613 & Turtle & United States \\
\hline F. solani $6 \mathrm{i}$ & NRRL28553 & DQ246894 & EU329548 & Human & United States \\
\hline F. solani $6 \mathrm{~g}$ & NRRL28016 & DQ246873 & EF470140 & Human & United States \\
\hline F. solani $6 \mathrm{e}$ & NRRL32849 & DQ247155 & EU329628 & Human eye & United States \\
\hline F. solani $6 \mathrm{~d}$ & NRRL32785 & DQ247094 & EU329618 & Human & United States \\
\hline F. solani 6a & NRRL43489 & DQ790484 & DQ790572 & Human eye & United States \\
\hline F. solani $34 \mathrm{a}$ & NRRL46703 & HM347126 & EU329661 & Nematode & Spain \\
\hline F. solani $25 \mathrm{a}$ & NRRL22389 & AF178340 & EU329506 & Liririodendron tulipfera & United States \\
\hline F. solani $22 \mathrm{a}$ & NRRL32751 & DQ247069 & EU329611 & Human eye & United States \\
\hline F. solani $20 \mathrm{a}$ & NRRL22608 & DQ247622 & EU329517 & Human & United States \\
\hline F. solani $14 \mathrm{a}$ & NRRL22611 & DQ246840 & EU329518 & Human eye & United States \\
\hline F. solani $12 \mathrm{~d}$ & NRRL32309 & DQ246937 & EU329571 & Human & United States \\
\hline F. solani $12 \mathrm{a}$ & NRRL22642 & DQ246844 & EU329522 & Fenneropenaeus spp. & Japan \\
\hline Fusarium plagianthi & NRRL22632 & AF178354 & JX171614 & Hoheria glabrata & New Zealand \\
\hline Fusarium pisi & NRRL22820 & AF178355 & EU329532 & Pisum sativum & United States \\
\hline Fusarium pisi & NRRL22278 & AF178337 & EU329501 & Pisum sativum & United States \\
\hline Fusarium pisi & NRRL45880 & FJ240352 & JX171655 & Pisum sativum & United States \\
\hline Fusarium phaseoli & CBS265.50 & HE647964 & KM232375 & Phaseolus sp. & United States \\
\hline Fusarium petroliphilum & NRRL28546 & DQ246887 & HM347152 & Human eye & United States \\
\hline Fusarium petroliphilum & NRRL43812 & EF453054 & EF470093 & Contact lens solution & United States \\
\hline Fusarium petroliphilum & NRRL32856 & DQ247161 & EU329629 & Hospital & United States \\
\hline Fusarium neocosmosporiellum & NRRL22166 & AF178350 & EU329497 & Heteroderma glycines & United States \\
\hline Fusarium neocosmosporiellum & NRRL43467 & EF469979 & EF469979 & Human eye & United States \\
\hline Fusarium neocosmosporiellum & NRRL22436 & AF178348 & EU329511 & Soil & South Africa \\
\hline Fusarium lichenicola & NRRL34123 & DQ247191 & EU329635 & Human eye & India \\
\hline Fusarium keratoplasticum & NRRL43433 & DQ790473 & DQ790561 & Human eye & United States \\
\hline Fusarium keratoplasticum & NRRL43445 & DQ790479 & DQ790567 & Human eye & United States \\
\hline Fusarium illudens & NRRL22090 & AF178326 & AF178392 & Beilshmiedia tawa & New Zealand \\
\hline Fusarium falciforme & NRRL43441 & DQ790478 & DQ790566 & Human eye & United States \\
\hline Fusarium euwallaceae & NRRL54722 & JQ038007 & JQ038028 & Persea americana & Israel \\
\hline Fusarium ambrosium & NRRL20438 & AF178332 & JX171584 & Camellia sinensis & India \\
\hline
\end{tabular}

y CBS, Centraalbureau voor Schimmelcultures Fungal Biodiversity Center, Utrecht, the Netherlands; NRRL, Agricultural Research Service Culture Collection, Peoria, IL.

${ }^{\mathrm{z}}$ EF1- $\alpha$, elongation factor 1- $\alpha ; R P B 2$, RNA polymerase II second largest subunit. 
in the growing area. In $7.7 \%$ of the greenhouses surveyed, the disease symptoms were associated with Phytophthora capsici. F. solani was also detected in the melon and watermelon greenhouses but not in any of the cucumber greenhouses inspected, where the disease symptoms were associated with Monosporascus cannonballus (data not shown).

Pathogenicity on zucchini plants and fruit. In the pathogenicity trials of $F$. solani on zucchini plants, all isolates tested, except PCl2121, were pathogenic to zucchini, reproducing the crown and foot rot symptoms (Supplementary Fig. S1). The first disease symptom observed was plant wilt observed at 16 and 9 days after inoculation (DAI) for the first and second trials, respectively. In the first trial, the most virulent isolates causing visible disease symptoms were PCl511, PCl-711, PCl-1641, and PCl-2211, and the less virulent ones were PCl-341 and PCl-1911, which showed the first diseased plants by 22 DAI. By 27 DAI, all of the pathogenic isolates had caused disease in at least $8 \%$ of the plants, and by $41 \mathrm{DAI}$, only $2 \%$ of the plants inoculated with PCl-1121 and $4 \%$ of the plants inoculated with PCl1911 remained asymptomatic. Three isolates showed a $100 \% \mathrm{M}$ rate by 41 DAI, namely PCl-1731, PCl-1811, and PCl-2111 (Table 2). In this trial, temperatures ranged from 6.4 to $34.9^{\circ} \mathrm{C}$ with a mean of $18.1^{\circ} \mathrm{C}$ in the greenhouse environment and from 14.4 to $28.7^{\circ} \mathrm{C}$ with a mean of $21.4^{\circ} \mathrm{C}$ in the substrate bags.

In the second trial, the most virulent isolates causing disease symptoms were $\mathrm{PCl}-511, \mathrm{PCl}-731$, and $\mathrm{PCl}-1731$, and the least virulent one was PCl-1121, which caused visible disease symptoms at 17 DAI. At 27 DAI, all of the pathogenic isolates had caused disease in at least $6 \%$ of the plants, and by $34 \mathrm{DAI}$, all of the inoculated plants, except one plant inoculated with $\mathrm{PCl}-341$ and another plant inoculated with PCl-1121, were diseased. By this date, all isolates had caused a $100 \% \mathrm{M}$ rate, except PCl-341, PCl-1121, PCl-1431, $\mathrm{PCl}-1911$, and $\mathrm{PCl}-2111$. In this trial, temperatures ranged from 18.5 to $37.1^{\circ} \mathrm{C}$ with a mean of $27.4^{\circ} \mathrm{C}$ in the greenhouse environment and from 23.5 to $37.1^{\circ} \mathrm{C}$ with a mean of $29.7^{\circ} \mathrm{C}$ in the substrate bags.

In both trials, the isolate $\mathrm{PCl}-1731$ was the most aggressive, showing an RAUDPC significantly higher than the rest and $\mathrm{M}$ rates of $100 \%$, and it was followed by the isolate PCl-1721; both were obtained from watermelon. In contrast, the isolates PCl-1121 and PCl-341 from zucchini produced the lowest RAUDPC. Noninoculated controls and plants inoculated with the isolate PCl-2121 remained asymptomatic (DI $=0 \%$ ). In both trials, the pathogen was successfully recovered from all plants selected for reisolation.

In fruits, all of the isolates, including PCl-2121, caused lesions, which consisted of brown, water-soaked rot that sometimes formed white mycelium on the surface. The fruit lesion growth rate ranged from 0.9 to $2.64 \mathrm{~mm} \mathrm{day}^{-1}$, corresponding to isolates $\mathrm{PCl}-341$ and $\mathrm{PCl}-2121$, respectively, the latter being the only isolate not pathogenic on zucchini stems. Fruits inoculated with uncolonized PDA plugs showed no symptoms (Table 2). $F$. solani isolates were successfully recovered from the lesions.

Pathogenicity on other horticultural crops. In the first pathogenicity trial on the various horticultural crops, all plants belonging to different plant families except cucurbits remained asymptomatic (data not shown). All species in the cucurbit family except cucumber showed aerial disease symptoms (Table 3 ). The first disease symptoms were observed at $11 \mathrm{DAI}$ when melon, zucchini, and the three

Table 2. Collection details, GenBank accession numbers for the elongation factor 1- $\alpha(E F 1-\alpha)$ and RNA polymerase II second largest subunit (RPB2) loci, and final disease parameters of the pathogenicity tests performed in zucchini plants and fruits of the strains of Fusarium solani species complex examined in this study

\begin{tabular}{|c|c|c|c|c|c|c|c|c|c|c|c|}
\hline \multirow[b]{4}{*}{ Isolate } & \multirow[b]{4}{*}{ Host } & \multirow[b]{4}{*}{ Year } & \multirow{3}{*}{\multicolumn{2}{|c|}{$\begin{array}{c}\text { GenBank accession } \\
\text { number }\end{array}$}} & \multicolumn{7}{|c|}{ Disease parameters } \\
\hline & & & & & \multicolumn{6}{|c|}{ Zucchini plants $^{x}$} & \multirow{3}{*}{$\frac{\text { Zucchini fruits }^{y}}{{\text { Fruit lesion }\left(m m \cdot \text { day }^{-1}\right)}^{-1}}$} \\
\hline & & & & & \multicolumn{3}{|c|}{ First trial } & \multicolumn{3}{|c|}{ Second trial } & \\
\hline & & & $E F 1-\alpha$ & $R P B 2$ & DI (\%) & M (\%) & RAUDPC & DI (\%) & M (\%) & RAUDPC & \\
\hline PCl-341 & Zucchini & 2007 & MK048138 & MK048118 & $100 \mathrm{a}$ & $54.17 \mathrm{a}$ & 0.28 ef & $97.92 \mathrm{a}$ & $97.92 \mathrm{a}$ & $0.42 \mathrm{fgh}$ & $0.95 \pm 0.28 \mathrm{kl}$ \\
\hline PCl-511 & Zucchini & 2009 & KF372878 & MK048117 & $100 \mathrm{a}$ & $85.42 \mathrm{a}$ & 0.50 bcde & $100 \mathrm{a}$ & $100 \mathrm{a}$ & $0.76 \mathrm{ab}$ & $0.86 \pm 0.121$ \\
\hline PCl-571 & Zucchini & 2009 & MK048152 & MK048116 & $100 \mathrm{a}$ & $91.67 \mathrm{a}$ & $0.58 \mathrm{abc}$ & $100 \mathrm{a}$ & $100 \mathrm{a}$ & 0.69 abcde & $1.13 \pm 0.20 \mathrm{jk}$ \\
\hline PCl-711 & Melon & 2009 & KC711040 & MK048120 & $100 \mathrm{a}$ & $95.83 \mathrm{a}$ & $0.55 \mathrm{abcd}$ & $100 \mathrm{a}$ & $100 \mathrm{a}$ & $0.75 \mathrm{abc}$ & $1.73 \pm 0.49 \mathrm{~cd}$ \\
\hline PCl-731 & Melon & 2009 & KC711041 & MK048119 & $100 \mathrm{a}$ & $95.83 \mathrm{a}$ & $0.58 \mathrm{abc}$ & $100 \mathrm{a}$ & $100 \mathrm{a}$ & $0.77 \mathrm{ab}$ & $1.54 \pm 0.34 \mathrm{de}$ \\
\hline PCl-1021 & Zucchini & 2010 & MK048151 & MK048132 & $100 \mathrm{a}$ & $93.75 \mathrm{a}$ & 0.51 bcde & $100 \mathrm{a}$ & $100 \mathrm{a}$ & $0.70 \mathrm{abcd}$ & $1.24 \pm 0.27 \mathrm{hij}$ \\
\hline PCl-1111 & Zucchini & 2011 & MK048150 & MK048123 & $100 \mathrm{a}$ & $83.33 \mathrm{a}$ & 0.53 bcde & $100 \mathrm{a}$ & $100 \mathrm{a}$ & $0.81 \mathrm{ab}$ & $1.80 \pm 0.43 \mathrm{bc}$ \\
\hline PCl-1121 & Zucchini & 2011 & MK048149 & MK048122 & $97.92 \mathrm{a}$ & $39.58 \mathrm{~b}$ & $0.27 \mathrm{ef}$ & $97.92 \mathrm{a}$ & $70.83 \mathrm{~b}$ & $0.28 \mathrm{gh}$ & $1.18 \pm 0.27 \mathrm{ij}$ \\
\hline PCl-1421 & Zucchini & 2011 & MK048148 & MK048115 & $100 \mathrm{a}$ & $97.92 \mathrm{a}$ & $0.66 \mathrm{ab}$ & $100 \mathrm{a}$ & $100 \mathrm{a}$ & 0.69 abcd & $1.15 \pm 0.18 \mathrm{j}$ \\
\hline PCl-1431 & Zucchini & 2011 & MK048147 & MK048114 & $100 \mathrm{a}$ & $89.58 \mathrm{a}$ & $0.59 \mathrm{abc}$ & $100 \mathrm{a}$ & $95.83 \mathrm{a}$ & 0.51 defgh & $1.14 \pm 0.19 \mathrm{j}$ \\
\hline PCl-1511 & Zucchini & 2011 & MK048136 & MK048131 & $100 \mathrm{a}$ & $95.83 \mathrm{a}$ & $0.56 \mathrm{abcd}$ & $100 \mathrm{a}$ & $100 \mathrm{a}$ & 0.72 abcd & $1.96 \pm 0.32 \mathrm{~b}$ \\
\hline PCl-1521 & Zucchini & 2011 & MK048146 & MK048129 & $100 \mathrm{a}$ & $72.92 \mathrm{a}$ & 0.45 cdef & $100 \mathrm{a}$ & $100 \mathrm{a}$ & 0.55 cdefgh & $1.08 \pm 0.24 \mathrm{jk}$ \\
\hline PCl-1621 & Zucchini & 2011 & MK048145 & MK048124 & $100 \mathrm{a}$ & $93.75 \mathrm{a}$ & 0.53 bcde & $100 \mathrm{a}$ & $100 \mathrm{a}$ & 0.61 bcdefg & $1.34 \pm 0.28 \mathrm{fghi}$ \\
\hline PCl-1721 & Watermelon & 2011 & MK048144 & MK048125 & $100 \mathrm{a}$ & $97.92 \mathrm{a}$ & $0.70 \mathrm{ab}$ & $100 \mathrm{a}$ & $100 \mathrm{a}$ & $0.81 \mathrm{ab}$ & $0.90 \pm 0.201$ \\
\hline PCl-1731 & Watermelon & 2011 & MK048143 & MK048126 & $100 \mathrm{a}$ & $100 \mathrm{a}$ & $0.73 \mathrm{a}$ & $100 \mathrm{a}$ & $100 \mathrm{a}$ & $0.84 \mathrm{a}$ & $1.18 \pm 0.25 \mathrm{ij}$ \\
\hline PCl-1811 & Zucchini & 2011 & MK048142 & MK048127 & $100 \mathrm{a}$ & $100 \mathrm{a}$ & $0.56 \mathrm{abcd}$ & $100 \mathrm{a}$ & $100 \mathrm{a}$ & 0.62 bcdefg & $1.11 \pm 0.21 \mathrm{jk}$ \\
\hline PCl-1821 & Zucchini & 2011 & MK048141 & MK048128 & $100 \mathrm{a}$ & $95.83 \mathrm{a}$ & $0.56 \mathrm{abcd}$ & $100 \mathrm{a}$ & $100 \mathrm{a}$ & $0.71 \mathrm{abcd}$ & $1.76 \pm 0.49 c$ \\
\hline PCl-1911 & Zucchini & 2011 & MK048140 & MK048130 & $95.83 \mathrm{a}$ & $60.42 \mathrm{a}$ & $0.35 \mathrm{def}$ & $100 \mathrm{a}$ & $89.58 \mathrm{c}$ & 0.47 efgh & $1.51 \pm 0.27$ ef \\
\hline PCl-2111 & Zucchini & 2011 & MK048139 & MK048133 & $100 \mathrm{a}$ & $100 \mathrm{a}$ & $0.60 \mathrm{abc}$ & $100 \mathrm{a}$ & $95.83 \mathrm{a}$ & 0.64 abcdef & $1.43 \pm 0.19 \mathrm{efg}$ \\
\hline PCl-2121 & Zucchini & 2011 & MK048134 & MK048110 & $0 \mathrm{~b}$ & $0 \mathrm{~b}$ & $0 \mathrm{f}$ & $0 \mathrm{~b}$ & $0 \mathrm{~d}$ & $0 \mathrm{~h}$ & $2.64 \pm 0.33 \mathrm{a}$ \\
\hline PCl-2211 & Zucchini & 2012 & MK048137 & MK048113 & $100 \mathrm{a}$ & $95.83 \mathrm{a}$ & $0.65 \mathrm{ab}$ & $100 \mathrm{a}$ & $100 \mathrm{a}$ & 0.61 bcdefg & $1.41 \pm 0.23 \mathrm{efgh}$ \\
\hline PCl-2321 & Zucchini & 2012 & MK048135 & MK048121 & $100 \mathrm{a}$ & $97.91 \mathrm{a}$ & $0.64 \mathrm{ab}$ & $100 \mathrm{a}$ & $100 \mathrm{a}$ & 0.70 abcd & $1.25 \pm 0.24$ ghij \\
\hline PCl-25F1 & Asparagus & 2008 & MK048154 & MK048108 & $\mathrm{n} / \mathrm{a}^{\mathrm{z}}$ & $\mathrm{n} / \mathrm{a}$ & $\mathrm{n} / \mathrm{a}$ & $\mathrm{n} / \mathrm{a}$ & $\mathrm{n} / \mathrm{a}$ & $\mathrm{n} / \mathrm{a}$ & $\mathrm{n} / \mathrm{a}$ \\
\hline $\mathrm{PCl}-25 \mathrm{~F} 2$ & Pepper & 2008 & MK048156 & MK048112 & $\mathrm{n} / \mathrm{a}$ & $\mathrm{n} / \mathrm{a}$ & $\mathrm{n} / \mathrm{a}$ & $\mathrm{n} / \mathrm{a}$ & $\mathrm{n} / \mathrm{a}$ & $\mathrm{n} / \mathrm{a}$ & $\mathrm{n} / \mathrm{a}$ \\
\hline $\mathrm{PCl}-25 \mathrm{~F} 3$ & Green bean & 2008 & MK048155 & MK048109 & $\mathrm{n} / \mathrm{a}$ & $\mathrm{n} / \mathrm{a}$ & $\mathrm{n} / \mathrm{a}$ & $\mathrm{n} / \mathrm{a}$ & $\mathrm{n} / \mathrm{a}$ & $\mathrm{n} / \mathrm{a}$ & $\mathrm{n} / \mathrm{a}$ \\
\hline $\mathrm{PCl}-25 \mathrm{~F} 4$ & Orange tree & 2009 & MK048153 & MK048111 & $\mathrm{n} / \mathrm{a}$ & $\mathrm{n} / \mathrm{a}$ & $\mathrm{n} / \mathrm{a}$ & $\mathrm{n} / \mathrm{a}$ & $\mathrm{n} / \mathrm{a}$ & $\mathrm{n} / \mathrm{a}$ & $\mathrm{n} / \mathrm{a}$ \\
\hline
\end{tabular}

${ }^{\mathrm{x}}$ Disease parameters obtained at the end of the two trials conducted expressed as the percentage of plants at the end of the experiment. Values in columns followed by different letters indicate significant differences according to the Kruskal-Wallis nonparametric analysis of variance $(P<0.05)$. DI, disease incidence; M, mortality; RAUDPC, relative area under the disease progress curve expressed as the proportion of the maximum potential area under the disease progress curve assessed by plotting the disease rates per plant on the basis of a 0 to 2 scale versus time with the trapezoidal method (Madden et al. 2007).

${ }^{y}$ Measurements of lesions caused in zucchini fruits after 7 days expressed as millimeters ${ }^{-} a^{-1}$. Values in columns followed by different letters indicate significant differences according to the least significant difference method $(P<0.05)$. Data of the two experiments were pooled prior to analyses.

$\mathrm{z}_{\mathrm{n}} \mathrm{a}$, not available. 
rootstock hybrids showed some diseased plants. Three days later at 14 DAI, there was at least one wilted plant per cucurbit species except cucumber. Plants were maintained up to 31 DAI owing to the height of the cucumber plants, which did not allow us to maintain the crop for a longer time. By that time, the species most affected was zucchini followed by melon, watermelon, and the three rootstock hybrids. Cucumber plants were asymptomatic because no visible wilting or crown rot was observed (Table 3). A detailed evaluation of the root system revealed necrosis in the root system of $100 \%$ of the plants, indicating the ability of the isolates to cause disease in this species. Temperatures in this trial ranged from 9 to $39.7^{\circ} \mathrm{C}$ with a mean of $21.5^{\circ} \mathrm{C}$ in the greenhouse environment and from 9.4 to $34^{\circ} \mathrm{C}$ with a mean of $21.2^{\circ} \mathrm{C}$ in the pots.

In the second trial, such as was observed in the previous one, only plants belonging to the cucurbit family showed disease symptoms, with the isolates being nonpathogenic to the other families. The first

Table 3. Disease parameter values for nine cucurbit species and cultivars tested for susceptibility to Fusarium solani f. sp. cucurbitae isolates PCl-511 and PCl1621 in greenhouse experiments during the two trials conducted

\begin{tabular}{|c|c|c|c|c|c|c|}
\hline \multirow[b]{2}{*}{ Species } & \multicolumn{3}{|c|}{ Trial 2013} & \multicolumn{3}{|c|}{ Trial 2014} \\
\hline & DI $(\%)$ & $\mathbf{M}(\%)$ & RAUDPC & DI $(\%)$ & $\mathbf{M}(\%)$ & RAUDPC \\
\hline Cucumis sativus 'Borja' & 0 & $0 \mathrm{c}$ & $0 \mathrm{c}$ & 91.6 & 80.5 & $0.37 \mathrm{c}$ \\
\hline Cucumis sativus 'Marketmore' & 0 & $0 \mathrm{c}$ & $0 \mathrm{c}$ & 88.9 & 77.8 & $0.26 \mathrm{c}$ \\
\hline Cucumis sativus 'Pepinillo Jardiver' & $\mathrm{n} / \mathrm{a}^{\mathrm{z}}$ & $\mathrm{n} / \mathrm{a}$ & $\mathrm{n} / \mathrm{a}$ & 88.9 & 80.6 & $0.24 \mathrm{c}$ \\
\hline Cucumis melo 'Amarillo Jardiver' & 97.2 & $97.2 \mathrm{a}$ & $0.64 \mathrm{a}$ & 100 & 100 & $0.77 \mathrm{ab}$ \\
\hline Cucurbita pepo 'Cónsul' & 100 & $97.2 \mathrm{a}$ & $0.62 \mathrm{a}$ & 100 & 100 & $0.88 \mathrm{a}$ \\
\hline Citrullus lanatus 'Mariola' & 97.2 & $63.9 \mathrm{~b}$ & $0.30 \mathrm{~b}$ & 100 & 100 & $0.70 \mathrm{~b}$ \\
\hline $\begin{array}{l}\text { Cucurbita maxima } \times \text { Cucurbita moschata } \\
\text { 'Hércules' }\end{array}$ & 94.4 & $44.4 \mathrm{~b}$ & $0.41 \mathrm{~b}$ & 100 & 91.7 & $0.71 \mathrm{ab}$ \\
\hline $\begin{array}{l}\text { Cucurbita maxima } \times \text { Cucurbita moschata } \\
\text { 'Titán' }\end{array}$ & 86.1 & $16.7 \mathrm{~b}$ & $0.26 \mathrm{~b}$ & 100 & 83.3 & $0.66 \mathrm{~b}$ \\
\hline $\begin{array}{l}\text { Cucurbita maxima } \times \text { Cucurbita moschata } \\
\text { 'RS-841' }\end{array}$ & 80 & $23.3 \mathrm{~b}$ & $0.24 \mathrm{~b}$ & 100 & 72.2 & $0.66 \mathrm{~b}$ \\
\hline
\end{tabular}

${ }^{y}$ Values in columns followed by different letters indicate significant differences according to the Kruskal-Wallis nonparametric analysis of variance $(P<0.05)$. DI, disease incidence expressed as the percentage of the total number of plants; $\mathrm{M}$, mortality; RAUDPC, relative area under the disease progress curve expressed as the proportion of the maximum potential area under the disease progress curve assessed by plotting the disease rates per plant on the basis of a 0 to 2 scale versus time with the trapezoidal method (Madden et al. 2007).

$\mathrm{z}$ n/a, not available.

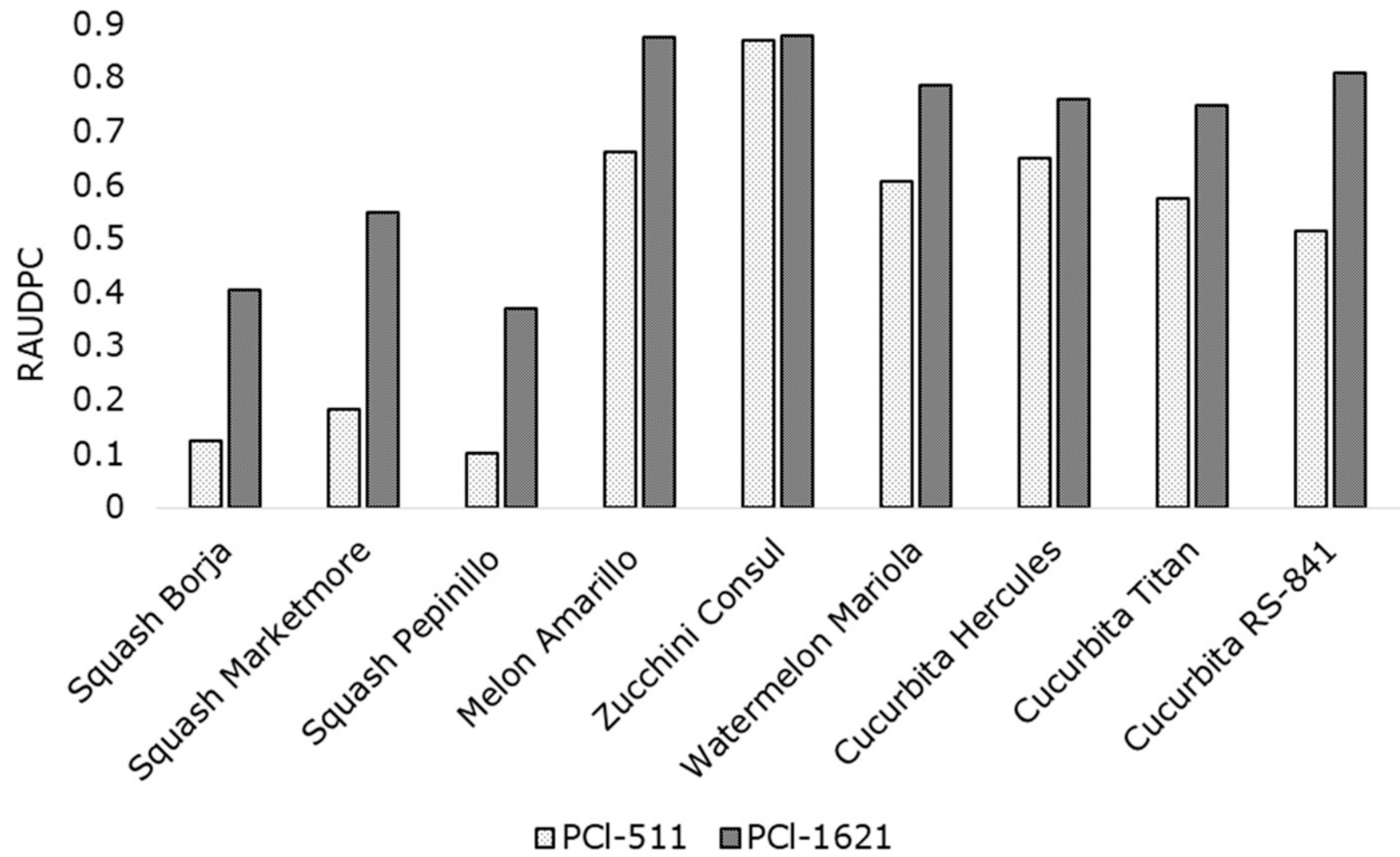

Fig. 1. Effect of Fusarium solani f. sp. cucurbitae inoculation with the isolates $\mathrm{PCl}-511$ and $\mathrm{PCl}-1621$ on different cucurbit species and hybrids. Data correspond to the final relative area under the disease progress curve (RAUDPC) calculated as the proportion of the maximum possible area under the disease progress curve assessed by plotting the rating on the basis of a 0 to 2 scale versus time, with the trapezoidal method (Madden et al. 2007) calculated 60 days after the inoculation in the second trial to evaluate the pathogenicity of F. solani f. sp. cucurbitae to several horticultural crops. 
disease symptoms were observed at $8 \mathrm{DAI}$, and as in the previous year, all species except cucumber and watermelon were the most susceptible. The first watermelon plants showed wilt symptoms at 12 DAI; the cucumber cultivars Marketmore and Borja displayed the first wilted plants at $26 \mathrm{DAI}$, whereas the cultivar Pepinillo Jardiver displayed symptoms at 29 DAI. By 29 DAI, the DI for zucchini and the three Cucurbita hybrids was $100 \%$; melon and watermelon displayed 91.7 and $86.1 \%$ DI, respectively; and the cucumber cultivars Marketmore, Borja, and Pepinillo Jardiver displayed 13.9, 41.7, and $11.1 \%$ DI, respectively. Plants were maintained in the greenhouse for a total of 60 DAI when the DI for all of the cucurbits tested, except cucumber, was $100 \%$. M for melon, zucchini, and watermelon was
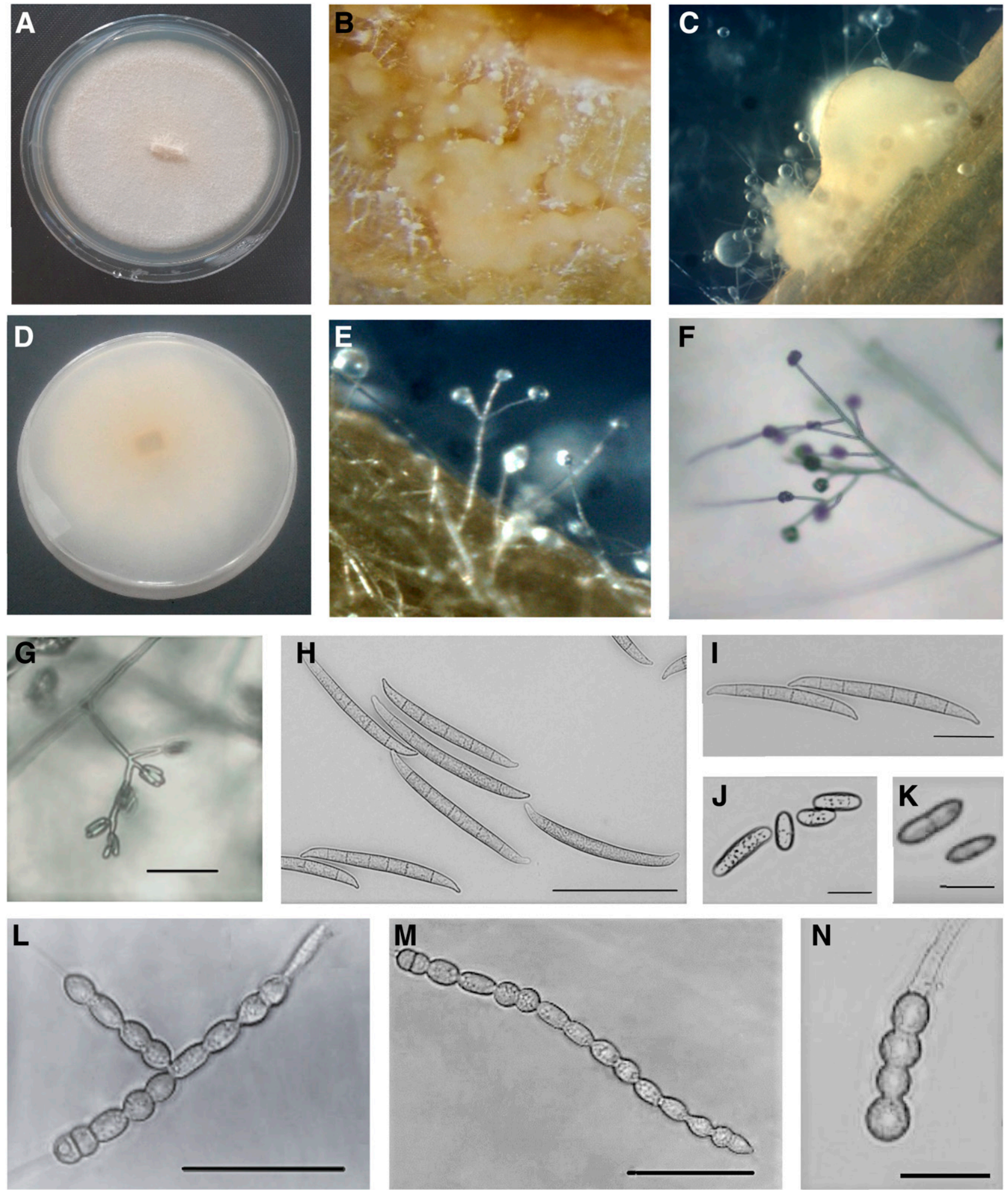

Fig. 2. Morphological description of Fusarium solani f. sp. cucurbitae. A and D, Growth on potato dextrose agar (PDA). B and C, Yellow sporodochia after 10 days on pieces of carnation leaves on carnation leaf-piece agar (CLA). E to G, Long and branched conidiophores producing zero- to one-septate microconidia. $\mathbf{H}$ and I, Macroconidia produced in CLA. J and K, Microconidia produced in PDA. L and M, Long chains of intercalary chlamydospores produced in PDA. N, Terminal chlamydospores produced in PDA. Scale bars: $\mathrm{H}, \mathrm{L}$, and $\mathrm{M}, 50 \mu \mathrm{m} ; \mathrm{G}, \mathrm{I}$, and $\mathrm{N}, 20 \mu \mathrm{m} ; \mathrm{J}$ and $\mathrm{K}, 10 \mu \mathrm{m}$. 
$100 \%$, and the $\mathrm{M}$ for the rest of the cucurbits was between 91.7 and $72.2 \%$ (Table 3). In this trial, temperatures ranged from 12.3 to $39.5^{\circ} \mathrm{C}$ with a mean of $23.6^{\circ} \mathrm{C}$ in the greenhouse environment and from 21.3 to $35.4^{\circ} \mathrm{C}$ with a mean of $27.5^{\circ} \mathrm{C}$ in the substrate bags.

When comparing the ability of the two isolates to cause disease on the different cucurbit hosts, a higher aggressiveness was observed in PCl-1621 compared with PCl-511 in both experiments. In the first trial by $11 \mathrm{DAI}$ and in second trial by $8 \mathrm{DAI}$, the isolate PCl-511 had only caused visible disease in zucchini, whereas PCl-1621 had caused disease symptoms in melon, zucchini, and the three Cucurbita hybrids. In watermelon in the first trial, one plant inoculated with PCl-511 showed symptoms at 14 DAI, and no other plants were symptomatic until 21 DAI when several plants inoculated with both isolates were wilted. In the second trial, the first disease symptoms were observed in watermelon plants by $12 \mathrm{DAI}$, and in cucumber, they were observed by 26 and 29 DAI. In both cases, they were produced by PCl-1621, whereas in all cases, plants inoculated with PCl511 remained asymptomatic by those dates. The final RAUDPC data per species and isolate of the second experiment are presented in Figure 1.

Morphology. Culture characteristics. Colonies on PDA showed radial growth rates of 8 to $8.5 \mathrm{~mm} \mathrm{day}^{-1}$ at $23^{\circ} \mathrm{C}$ and 7.8 to $9.1 \mathrm{~mm} \mathrm{day}^{-1}$ at $29^{\circ} \mathrm{C}$ in the dark, reaching a diameter of 51 to $57 \mathrm{~mm}$ after 6 days at $26^{\circ} \mathrm{C}$. Colony surface was white and cottony with white to straw aerial mycelium and sporulation abundant; colony margins were regular to slightly undulate and reverse white to pale straw (Fig. 2).

Cardinal temperatures for growth. Temperatures were a minimum of $8^{\circ} \mathrm{C}$, a maximum of $35^{\circ} \mathrm{C}$, and an optimum of 23 to $29^{\circ} \mathrm{C}$ (Fig. 3).

Sporulation abundant from conidiophores formed on aerial mycelium, on the agar surface, and from sporodochia. Conidiophores were straight, long, solitary, and simple or branched one to several times verticillately or sympodially, with each branch bearing a single terminal monophialide. Microconidia formed on aerial conidiophores, clustered in false heads at the tip of monophialides, hyaline, oval or obovoid with a truncate base, symmetrical or gently bent dorsoventrally, smooth and thin walled, $0-(1)$ septate. Zero-septate conidia were (5.8) 7.0-10.4 (12.9) × (3.1) 3.9-5.3 (5.9) $\mu \mathrm{m}$. One-septate conidia (11.1) 12.7-17.5 (21.0) × (3.9) 4.8-6.3 (6.7) $\mu \mathrm{m}$. Creamcolored sporodochia formed abundantly on the surface of carnation leaves. Sporodochial macroconidia showed slight to moderate dorsal curvature, elongate and slender, apical cell blunt or papilate, sporadically hooked, more or less equally sized than the adjacent cell, basal cell barely or distinctly notched, (3) 4-5 (6-7) septate, hyaline, thin and smooth walled. Three-septate conidia were (34.3) 37.2-46.5 (48.7) $\times$ (4.1) 4.5-5.6 (6) $\mu \mathrm{m}$. Four-septate conidia were (45.9) 49.4-58.8 (64.7) $\times(3.4) 4.5-5.8(6.8) \mu \mathrm{m}$. Five-septate conidia were (55) 57.9-64.1 (67.6) × (3.9) 4.6-5.8 (6.3) $\mu \mathrm{m}$. Six-septate conidia were (68.6) 74.6-90.7 (101.5) × (4.1) 4.8-6 (7.1) $\mu \mathrm{m}$. Overall was (34.3) 44.2-75.7 (101.5) × (3.4) 4.6-5.8 (7.1) $\mu \mathrm{m}$. Chlamydospores were abundant and rapidly formed on agar media (approximately 10 days), hyaline to pale brown, spherical to subspherical (5.9) 8.3-10.8 (12) $\mu \mathrm{m}$ in diameter, solitary in pairs or in chains, terminal or intercalar, and smooth and thick walled (Fig. 2).

Phylogeny. Phylogenetic analyses inferred from the EF1- $\alpha$ and $R P B 2$ datasets resolved the position of all of the isolates included in this study within the FSSC clade 3 in relation to currently recognized monophyletic species. The single and combined EF1- $\alpha$ and $R P B 2$ datasets included 76 strains. The EF1- $\alpha$ tree consisted of 436 characters, of which 142 characters were parsimony informative $(\mathrm{CI}=0.67, \mathrm{RI}=0.89)$ (Supplementary Fig. $\mathrm{S} 2)$; the $R P B 2$ tree consisted of 555 characters, of which 165 characters were parsimony informative (Supplementary Fig. S3) $(\mathrm{CI}=0.59$, RI $=0.85)$, and the combined EF1- $\alpha$ and RPB2 dataset consisted of 1,011 nucleotides,

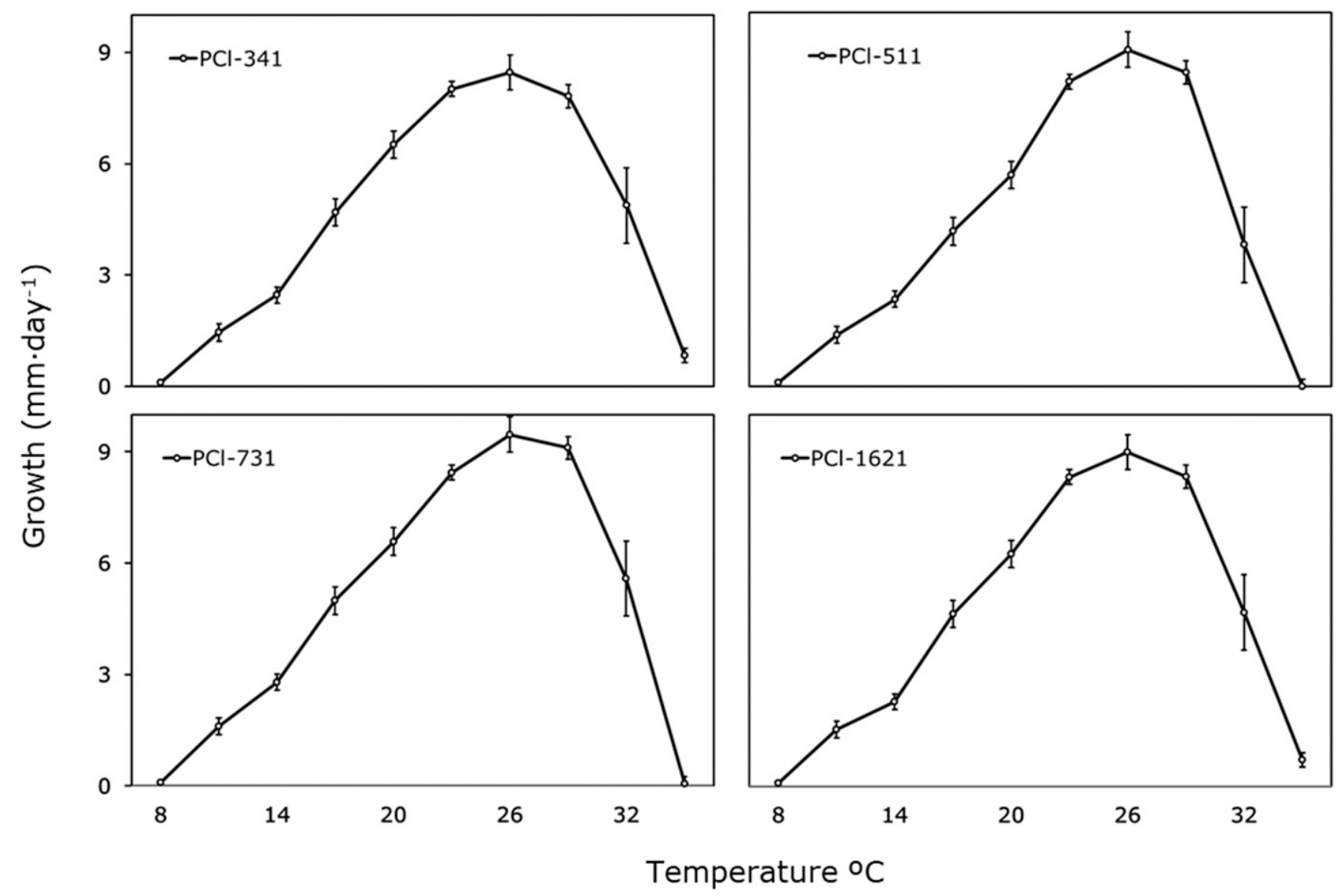

Fig. 3. Growth rates per day on potato dextrose agar of isolates $\mathrm{PCl}-341, \mathrm{PCl}-511, \mathrm{PCl}-731$, and $\mathrm{PCl}-1621$ measured after 6 days of incubation in constant dark at temperatures ranging from 8 to $35^{\circ} \mathrm{C}$ in $3^{\circ} \mathrm{C}$ intervals and expressed in millimeters day ${ }^{-1}$. 
of which 307 were parsimony informative (Fig. 4) $(\mathrm{CI}=0.61, \mathrm{RI}=$ 0.86). Phylogenetic analysis resulted in the 92 most parsimonious trees. No major topological differences were detected between Bayesian, neighbor-joining, and maximum parsimony phylogenetic inferences (data not shown).

In the three inferences, all of the isolates pathogenic to zucchini clustered together with the only two available $F$. solani f. sp. cucurbitae sequences in GenBank, NRRL22098, and NRRL22153, forming a monophyletic group with $100 \%$ bootstrap support. The single $R P B 2$ and combined EF1- $\alpha$ and $R P B 2$ datasets generated two F. solani f. sp. cucurbitae lineages, one of them containing eight isolates from Spain that are grouped with isolates NRRL22098 and NRRL22153 and another one containing isolates exclusively from Spain; however, only the second lineage presented bootstrap support. The isolate NRRL22570, corresponding to $F$. solani $\mathrm{f}$. sp. piperis, was resolved as the sister group of the $F$. solani $\mathrm{f}$. sp. cucurbitae group.

The remaining isolates included in this study, nonpathogenic to zucchini, were also placed in the FSSC clade 3; however, their positions varied. According to the combined loci phylogeny, the isolate $\mathrm{PCl}-2121$, pathogenic on zucchini fruit, was placed in the Fusarium keratoplasticum linage with a bootstrap value of $81 \%$. The isolates $\mathrm{PCl}-25 \mathrm{~F} 1$ and $\mathrm{PCl}-25 \mathrm{~F} 3$ isolated from asparagus and bean, respectively, were placed in the Fusarium falciforme linage with a bootstrap value of $81 \%$. The isolate $\mathrm{PCl}-25 \mathrm{~F} 2$, isolated from pepper (Capsicum annuum), was clustered in the Fusarium striatum linage with $100 \%$ bootstrap value. The isolate $\mathrm{PCl}-25 \mathrm{~F} 4$, obtained from orange tree roots, clustered with $F$. solani sensu stricto strains NRRL253888 and NRRL32737; bootstrap support was only observed for the combined $E F 1-\alpha$ and $R P B 2$ datasets (Fig. 4).

\section{Discussion}

The results from our study indicate that $F$. solani f. sp. cucurbitae is the main soilborne fungus affecting adult zucchini plants in the province of Almería, being the problem of less importance in melon and watermelon crops. F. solani f. sp. cucurbitae was detected in $88.4 \%$ of the greenhouses surveyed. The disease caused by this fungus frequently associated with greenhouses dedicated to zucchini monoculture because this is a common practice in the area. The symptoms observed both in the commercial greenhouses as well as in the artificial inoculations reproduced the typical brown crown rot described by previous authors (Bourbos et al. 1997; Champaco et al. 1993; Doidge and Kresfelder 1932; Fantino et al. 1989; García-Jiménez et al. 1997; Mehl and Epstein 2007; Snyder and Hansen 1941). Phytophthora capsici was also detected, causing disease in adult zucchini plants (Gómez et al. 2013). In all of the diseased cucumber plants found in commercial greenhouses, perithecia of Monosporascus cannonballus were consistently observed and isolated; however, after several pathogenicity tests on adult plants grown in perlite bags, the symptoms could not be reproduced (data not shown).

With respect to pathogenicity, all of the $F$. solani f. sp. cucurbitae isolates studied were highly virulent to zucchini. The isolate PCl-2121 was not pathogenic, and it was identified based on phylogenetic analysis as F. keratoplasticum. In our trials, almost $100 \%$ of the plants inoculated with $F$. solani f. sp. cucurbitae showed disease symptoms relatively early (by 44 and $38 \mathrm{DAI}$ ) in the first and second trials, respectively. In addition, large numbers of plants were dead by those dates, with $\mathrm{M}$ rates of 67 to $100 \%$ in the first trial and 73 to $100 \%$ in the second trial. The two trials were conducted consecutively in winter and spring 2013. Disease development was favored in the second trial, most likely because of the

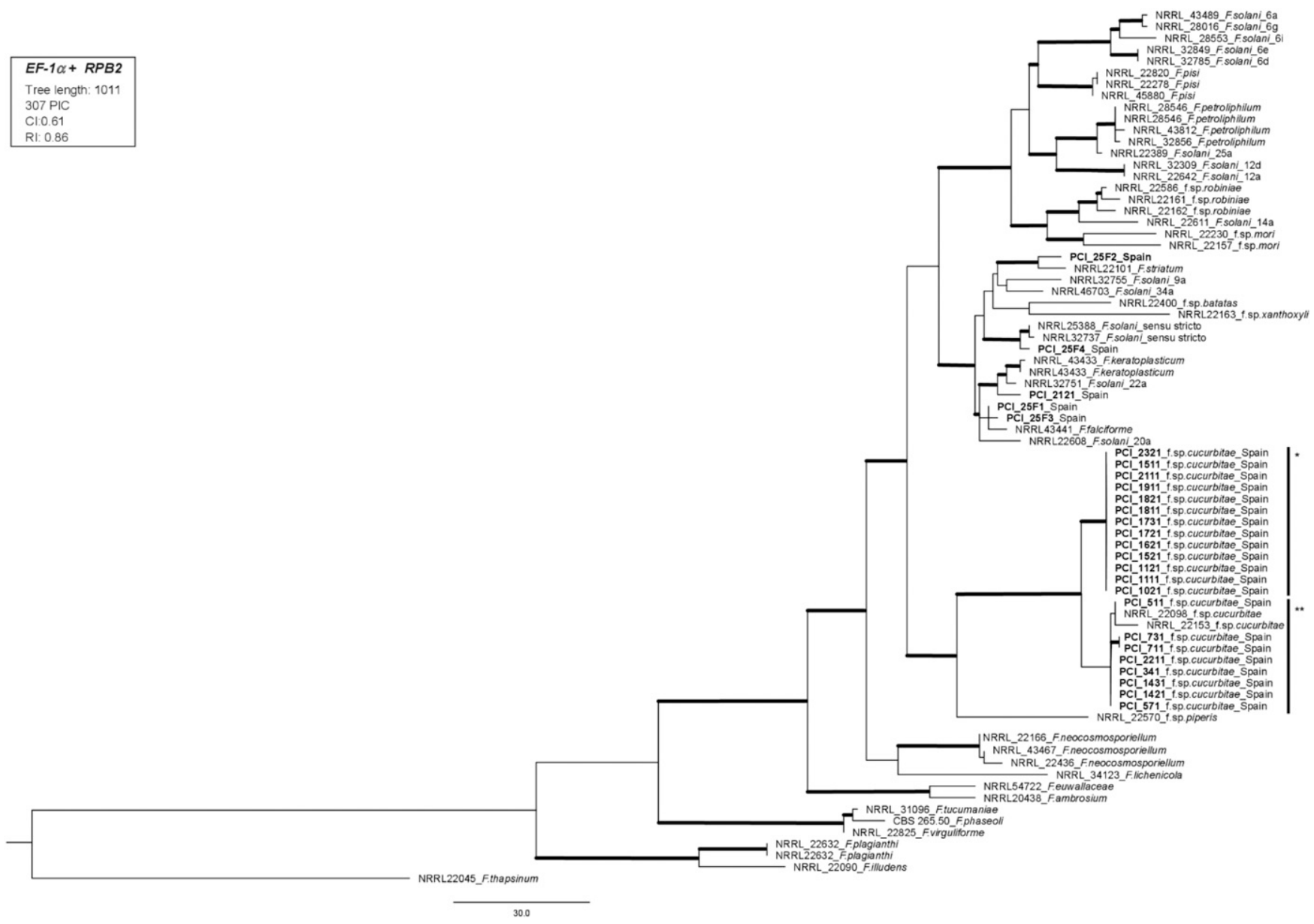

Fig. 4. One of the most parsimonious trees of the Fusarium solani species complex inferred from the elongation factor 1- $\alpha(E F 1-\alpha)+$ RNA polymerase II second largest subunit (RPB2) combined gene sequences. The dataset comprised 1,011 bp of aligned sequence data. The phylogram was rooted with Fusarium thapsinum NRRL22045. Bold lines indicate bootstrap values $>70 \%$ based on 1,000 pseudoreplicates. Cl, consistency index; PIC, parsimony informative; RI, retention index. ${ }^{*}$ Lineage composed of $F$. solani f. sp. cucurbitae isolates from Spain (bootstrap 70.9\%). ${ }^{*}$ Lineage clustering isolates from Spain and the U.S.A. (no bootstrap support). 
higher temperatures. In the first experiment, the average temperature measured in the substrate bags was $21.4^{\circ} \mathrm{C}$; however, in the second experiment, the mean temperature in the substrate bags was $29.7^{\circ} \mathrm{C}$, which is closer to the optimal temperature range assessed in our in vitro experiments (i.e., between 26 and $29^{\circ} \mathrm{C}$ ). These results are in agreement with those of Miguel (2001). Another study performed previously to compare different $F$. solani isolates obtained from sweet pepper plants and $F$. solani f. sp. cucurbitae reported the highest growth rate at $30^{\circ} \mathrm{C}$ (Paternotte 1987). In our morphological studies, the daily growth at $23^{\circ} \mathrm{C}$ was between 8 and $8.5 \mathrm{~mm} \mathrm{day}^{-1}$ on PDA. Camilo (2001) reported a daily growth of 6.11 to $6.22 \mathrm{~mm} \mathrm{day}^{-1}$ at the same temperature; however, these data differ from the description in the work by Sandoval-Denis et al. (2019), who observed an average daily growth of 2.4 to $4.2 \mathrm{~mm} \mathrm{day}^{-1}$ at $24^{\circ} \mathrm{C}$.

In addition to studying the pathogenicity on whole zucchini plants, zucchini fruits cultivar Cónsul were inoculated with the same strains to study the ability of the fungus to cause fruit rot. In this case, all isolates were able to produce visible fruit rot. In both trials, PCl-2121 caused the highest growth in the zucchini fruits, being significantly higher than the rot produced by the $F$. solani $\mathrm{f}$. sp. cucurbitae strains. Although fruit rot was observed in laboratory experiments, these symptoms were not observed in the diseased plants in the field, probably because the fruits are normally harvested in the immature state and because of the lack of contact between the fruit and soil.

Our phylogenetic inference placed the isolate $\mathrm{PCl}-2121$ in the $F$. keratoplasticum lineage, an opportunistic pathogen causing human eye infections (Chang et al. 2006). In 2018, Šišić et al. (2018) recovered $F$. keratoplasticum from naturally diseased pea, showing its potential pathogenicity to this plant species. This has clinical importance because plant debris and soil may be a potential source of infection for farmers and crop workers (Šišić et al. 2018). F. keratoplasticum commonly occurs in plumbing biofilms and is among the most frequent etiological agents of fusarial keratitis together with $F$. petroliphilum (Short et al. 2013). Most known F. keratoplasticum and $F$. petroliphilum isolates have been obtained from plumbing, infected humans, or animals (Mehl and Epstein 2008; Short et al. 2011, 2013; Zhang et al. 2006); however, F. petroliphilum was considered to be $F$. solani f. sp. cucurbitae race 2 because of its pathogenicity to cucurbit fruit in naturally infested fields until it was reclassified in 2013. In addition, F. keratoplasticum was isolated from zucchini in this study and also, from pea, indicating the plasticity of this FSSC member to colonize different environments and the potential threat to growers and field workers.

The greenhouse data on the host range of $F$. solani f. sp. cucurbitae are in agreement with previous reports that limit the host range of this forma specialis to cucurbits (Miguel 2001; Paternotte 1987; Tousson and Snyder 1961). In our trials, all plants evaluated belonging to the cucurbit family were susceptible to the pathogen. The rest of the plants belonging to other families were asymptomatic, and the fungus could not be recovered from these plants. Within the cucurbit species tested, differences in susceptibility were observed. Based on previous trials performed with zucchini, we conducted a first host range experiment in pots placed on benches, inoculating the plants in the seedling stage. The $F$. solani f. sp. cucurbitae isolates produced visible crown rot a few weeks after inoculation in several melon, watermelon, zucchini, and Cucurbita rootstock hybrids. Under the same conditions, cucumber plants were able to remain asymptomatic, but rot was observed below the soil level when the plants were removed and the root system was evaluated for symptoms. This led us to repeat the trial with the same design but in perlite bags to maintain the plants in the greenhouse for a longer period. In the second trial, the same tendency was observed, with melon, zucchini, and watermelon plants being the most susceptible plants closely followed by the Cucurbita hybrids. Cucumber plants remained asymptomatic for a longer period of time compared with the rest of the cucurbits. At 26 DAI, the first wilted cucumber plants were observed, and by the end of the experiment, 20 to $31 \%$ of the plants had remained asymptomatic, indicating that, although this species is also a suitable host for Fusarium crown and foot rot, it is a less susceptible host for the disease.
The phylogeny inferred from the combined $E F 1-\alpha$ and $R P B 2$ datasets as well as the single-gene phylogenies placed our isolates within clade 3 of the FSSC as previously reported in other studies (Chang et al. 2006; O'Donnell 2000; O'Donnell et al. 2008; SandovalDenis et al. 2019; Zhang et al. 2006). The isolates characterized as F. solani f. sp. cucurbitae were clustered together with NRRL22098 and NRRL22153 with $100 \%$ bootstrap support, suggesting that they correspond to the same phylogenetic species, with $F$. solani $\mathrm{f}$. sp. piperis as the ancestral group as previously reported in other FSSC phylogenies (O'Donnell 2000; O'Donnell et al. 2008; Short et al. 2013; Šišić et al. 2018). The combined EF1- $\alpha$ and RPB2 datasets separated the $F$. solani f. sp. cucurbitae into two lineages, one of them containing only Spanish isolates, with identical haplotypes (bootstrap $85.2 \%$ for the RPB2 and $70.9 \%$ for the combined dataset). The other linage contains the rest of the isolates together with NRRL22098 and NRRL22153; these isolates have previously been identified as pathogenic to cucurbits (Elmer et al. 2007; O'Donnell 2000). This group is more diverse, containing different haplotypes, and it did not receive bootstrap support. Our inference suggests that the first linage could have been diverged in our region after the introduction of $F$. solani $\mathrm{f}$. sp. cucurbitae. To resolve this, more loci should be included for the phylogenetic inference, and a wider disease survey conducted in different regions of Spain would shed light on this hypothesis.

With respect to morphology, our study reveals some variations to the traditional description of $F$. solani. Although $F$. solani produces relatively wide, straight, stout, and robust macroconidia, mostly three or four septate (Schroers et al. 2016), the F. solani f. sp. cucurbitae isolates produce relatively long and slender macroconidia, mostly five septate measuring $>55 \mu \mathrm{m}$ and less frequently, six septate measuring $>75 \mu \mathrm{m}$. These results are concordant with the observations made by Paternotte (1987), who found that conidia from $F$. solani f. sp. cucurbitae were up to five septate and more slender than conidia of $F$. solani from pepper, which were up to three septate. These observations are in agreement with the description of SandovalDenis et al. (2019), who described the macroconidia as long and narrow. Sandoval-Denis et al. (2019), however, reported macroconidia up to nine septate, and we have never observed macroconidia containing more than seven septa in any of the isolates included in this study.

In addition, in our $F$. solani $\mathrm{f}$. sp. cucurbitae isolates, the conidiophores were often verticillate, which is not common in the $F$. solani morphological description (Leslie and Summerell 2006; Nelson et al. 1994; Schroers et al. 2016), and this was not reported by SandovalDenis et al. (2019), who described conidiophores rarely sparingly branched. We also observed chlamydospores forming long chains, which is a characteristic that has never been described for $F$. solani f. sp. cucurbitae. Although our chlamydospores ranged between 5.9 and $12 \mu \mathrm{m}$ in diameter, Sandoval-Denis et al. (2019) described smaller chlamydospores ranging between 4 to 5 and $9 \mu \mathrm{m}$ in diameter.

Fusarium taxonomy has been controversial since the first description of this fungus by Link in 1908. The initial species descriptions were based exclusively on morphological or physiological characteristics, and the use of new approaches in the last decades, such as sexual compatibility or phylogenetic analysis, has challenged the morphological species description of the genus Fusarium because it has been demonstrated that many of those descriptions correspond to species complexes composed of distinct species that are morphologically indistinguishable (Leslie and Summerell 2006; Nelson et al. 1994; Zhang et al. 2006). The forma specialis nomenclature is an informal taxonomic rank that is also controversial (Amstrong and Amstrong 1981; Jacobson and Gordon 1991; Rossman and PalmHernández 2008). In several cases, species have been described and assigned to a forma specialis without proper host range tests, and this taxonomic classification provides no insights into the phylogeny or the evolutionary history of the pathogen (Al-Hatmi et al. 2018; Fourie et al. 2011; Śišić et al. 2018). This fact leads us to consider that there were two races of $F$. solani $\mathrm{f}$. sp. cucurbitae for decades until vegetative compatibility and phylogeny demonstrated 
that they correspond to two very distinct species (Matuo and Snyder 1973; Mehl and Epstein 2007; O'Donnell 2000; Zhang et al. 2006). In 2018, Šišić et al. (2018) reevaluated $F$. solani f. sp. pisi and assigned it to Fusarium pisi comb. nov. Šišić et al. (2018) confirmed the pathogenicity of this species to 33 hosts corresponding to 10 legume genera, which is in agreement with previous studies, expanding the host range of this forma specialis to chickpea (Cicer auriantum L) and other nonlegume hosts (Matuo and Snyder 1972; Westerlund et al. 1974). However, in 2012, Kolander et al. (2012) expanded the host range of Fusarium virguliforme (formerly $F$. solani f. sp. glycines) to several legumes, and the host range of Fusarium oxysporum f. sp. chrysanthemi was expanded in 2018 to orange coneflower (Rudbeckia fulgida) (Matić et al. 2018). Šišić et al. (2018) stress the confusion that the forma specialis nomenclature has caused in several cases and challenge this nomenclatural system, stating that it might deserve revision and formal taxonomic treatment. Similarly, several authors stress the necessity for proper species descriptions and nomenclatures to designate cryptic speciation within the FSSC (Debourgogne et al. 2010; O'Donnell 2000; Wang et al. 2011; Zhang et al. 2006).

Based on the phylogenetic data and the morphological differences between $F$. solani and $F$. solani $\mathrm{f}$. sp. cucurbitae, the definition of the latter to species rank within the FSSC by Sandoval-Denis et al. (2019) is supported.

\section{Acknowledgments}

We thank the Royal Botanic Gardens and Domain Trust of Sydney, Australia for hosting A. Pérez-Hernández. We also thank Ms. J. Ros for her indispensable technical assistance.

\section{Literature Cited}

Al-Hatmi, A. M. S., Ahmed, S. A., van Diepeningen, A. D., Drogari-Apiranthitou, M., Verweij, P. E., Meis, J. F., and de Hoog, G. S. 2018. Fusarium metavorans sp. nov.: The frequent opportunist 'FSSC6'. Med. Mycol. 56(suppl 1): S144-1S152.

Amstrong, G. M., and Amstrong, J. K. 1981. Pages 391-399 in: Fusarium: Diseases, Biology, and Taxonomy. P. E. Nelson, T. A. Tousson, and R. J. Cook, eds. Pennsylvania State University Press, University Park, PA.

Armengol, J., José, C., Moya, M., Sales, R., Vicent, A., and García-Jiménez, J. 2000. Fusarium solani f. sp. cucurbitae race 1, a potential pathogen of grafted watermelon production in Spain. EPPO Bull. 30:179-183.

Boughalleb, N., Tarchoun, N., El Mbarki, A., and El Mahjoub, M. 2007. Resistance evaluation of nine cucurbit rootstocks and grafted watermelon (Citrullus lanatus L.) varieties against fusarium wilt and fusarium crown and root rot. J. Plant Sci. 2:102-107.

Bourbos, V. A., Skoudridakis, M. T., Darakis, G. A., and Koulizakis, M. 1997. Calcium cyanamide and soil solarization for the control of Fusarium solani f. sp. cucurbitae in greenhouse cucumber. Crop Prot. 16:383-386.

Calvert, O. H., Williams, L. F., and Whitehead, M. D. 1960. Frozen-lima-bean agar for culture and storage of Phytophthora sojae. Phytopathology 50:136-137.

Camilo, M. J. 2001. Estudio de la podredumbre del cuello y frutos de calabaza causada por Fusarium solani (Mart.) Sacc. f. sp. cucurbitae W.C. Snyder \& H.N. Hans raza 1. Ph.D. Thesis. Universidad Politécnica de Valencia, Valencia, Spain.

Carbone, I., and Kohn, L. M. 1999. A method for designing primer sets for speciation studies in filamentous ascomycetes. Mycologia 91:553-556.

Champaco, E. R., Martyn, R. D., and Miller, M. E. 1993. Comparison of Fusarium solani and $F$. oxysporum as causal agents of fruit rot and root rot of muskmelon. HortScience 28:1174-1177.

Chang, D. C., Grant, G. B., O’Donnell, K., Wannemuehler, K. A., Noble-Wang, J., Rao, C. Y., Jacobson, L. M., Crowell, C. S., Sneed, R. S., Lewis, F. M. T., Schaffzin, J. K., Kainer, M. A., Genese, C. A., Alfonso, E. C., Jones, D. B., Srinivasan, A., Fridkin, S. K., and Park, B. J. 2006. A multistate outbreak of Fusarium keratitis associated with use of a new contact lens solution. J. Am. Med. Assn. 296:953-963.

Debourgogne, A., Gueidan, C., Hennequin, C., Contet-Audonneau, N., de Hoog, S., and Machouarta, M. 2010. Development of a new MLST scheme for differentiation of Fusarium solani species complex (FSSC) isolates. J. Microbiol. Methods 82: 319-323.

Doidge, E. M., and Kresfelder, L. J. 1932. A wilt disease of cucurbits. Farming S. Africa (Lond.) 7:299-300.

Drummond, A. J., Ashton, B., Buxton, S., Cheung, M., Cooper, A., Duran, C., Field, M., Heled, J., Kearse, M., Markowitz, S., Moir, R., Stones-Havas, S., Sturrock, S., Thierer, T., Wilson, A., 2011. Geneious v5.4. Geneious, Auckland, New Zealand.

Elmer, W. H., Covert, S. F., and O'Donnell, K. 2007. Investigation of an outbreak of Fusarium foot and fruit rot of pumpkin within the United States. Plant Dis. 91:1142-1146.
Fantino, M. G., Fantu, F. and Gennari, S. 1989. Study of squash rot caused by $F$ solani $\mathrm{f}$. sp. cucurbitae. Difesa delle Piante 12:147-153.

Fourie, G., Steenkamp, E. T., Ploetz, R. C., Gordon, T. R., and Viljoen, A. 2011 Current status of the taxonomic position of Fusarium oxysporum formae specialis cubense within the Fusarium oxysporum complex. Infect. Genet. Evol. 11:533-542.

García-Jiménez, J., Armengol, J., Moya, M. J., and Sales, R. 1997. First report of Fusarium solani f. sp. cucurbitae race 1 in Spain. Plant Dis. 81:1216.

Geiser, D. M., Jiménez-Gasco, M. M., Kang, B. S., Makalowska, I., Veeraraghavan, N., Ward, T. J., Zhang, N., Kuldau, G. A., O’Donnell, K., Kang, S. S., and Kuldau, G. A. 2004. FUSARIUM-ID v. 1.0: A DNA sequence database for identifying Fusarium. Eur. J. Plant Pathol. 110:473-479.

Gómez, J., Serrano, Y., Pérez, A., Porcel, E., Gómez, R., and Aguilar, M. I. 2014 Fusarium solani $\mathrm{f}$. sp. cucurbitae, affecting melon in Almería Province, Spain. Australas. Plant Dis. Notes 9:136.

Gómez, J. M., Guerra-Sanz, M. C., Sánchez-Guerrero, Y., Serrano, Y., and Melero-Vara, J. M. 2008. Crown rot of zucchini squash caused by Fusarium solani. F. sp. cucurbitae in Almería Province. Plant Dis. 92:1137.

Gómez, J. M., Serrano-Alonso, Y., Pérez-Hernández, A., Aguilar, M. I., and Gómez, R. M. 2013. Phytophthora crown and root rot of zucchini squash in Almería, Spain. Plant Dis. 97:1249.

Jacobson, D. J., and Gordon, T. R. 1991. Fusarium oxysporum f. sp. melonis: A case study of diversity within a forma specialis. Phytopathology 81:1064-1067.

Jeffers, S. N., and Martin, S. B. 1986. Comparison of two media selective for Phytophthora and Pythium species. Plant Dis. 70:1038-1043.

Khor, W. B., Aung, T., Saw, S. M., Wong, T. Y., Tambyah, P. A., Tan, A. L., Beuerman, R., Lim, L., Chan, W. K., Heng, W. J., Lim, J., Loh, R. S., Lee, S. B., and Tan, D. T. 2006. An outbreak of Fusarium keratitis associated with contact lens wear in Singapore. JAMA 295:2867-2873.

Kolander, T. M., Bienapfl, J. C., Kurle, J. E., and Malvick, D. K. 2012. Symptomatic and asymptomatic host range of Fusarium virguliforme, the causal agent of soybean sudden death syndrome. Plant Dis. 96:1148-1153.

Komada, H. 1975. Development of a selective medium for quantitative isolation of Fusarium oxysporum from natural soil. Rev. Plant Prot. Res. 8:114-125.

Leslie, J. F., and Summerell, B. A., eds. 2006. The Fusarium Laboratory Manual. Blackwell Publ., Ames, IA.

Liu, Y. L., Whelen, S., and Hall, B. D. 1999. Phylogenetic relationships among ascomycetes: Evidence from an RNA Polymerase II Subunit. Mol. Biol. Evol. 16:1799-1808.

Lombard, L., van der Merwe, N. A., Groenewald, J. Z., and Crous, P. W. 2015 Generic concepts in Nectriaceae. Stud. Mycol. 80:189-245.

Madden, L. V., Hughes, G., and van den Bosch, F. 2007. The Study of Plant Disease Epidemics. APS Press, St. Paul, MN.

MAPA. 2017. Anuario de Estadística Agraria. Superficie y producción. Ministerio de Agricultura, Pesca y Alimentación. https://www.mapa.gob.es/es/estadistica/ temas/publicaciones/anuario-de-estadistica/2018/default.aspx $?$ parte $=3 \&$ capitulo $=07$

Matić, S., Gilardi, G., Gullino, M. L., and Garibaldi, A. 2018. Evidence for an expanded host range of Fusarium oxysporum f. sp. chrysanthemi. J. Plant Pathol. 100:97-104.

Matuo, T., and Snyder, W. C. 1972. Host virulence and the Hypomyces stage of Fusarium solani $\mathrm{f}$. sp. pisi. Phytopathology 62:731-735.

Matuo, T., and Snyder, W. C. 1973. Use of morphology and mating populations in the identification of formae speciales in Fusarium solani. Phytopathology 63: 562-565.

Mehl, H. L., and Epstein, L. 2007. Fusarium solani species complex isolates conspecific with Fusarium solani f. sp. cucurbitae race 2 from naturally infected human and plant tissue and environmental sources are equally virulent on plants, grow at $37^{\circ} \mathrm{C}$ and are interfertile. Environ. Microbiol. 9: 2189-2199.

Mehl, H. L., and Epstein, L. 2008. Sewage and community shower drains are environmental reservoirs of Fusarium solani species complex group 1, a human and plant pathogen. Environ. Microbiol. 10:219-227.

Messiaen, C. M., Blancard, D., Rouxel, F., and Lafon, R. 1995. Enfermedades de las hortalizas. Ediciones Mundi-Prensa, Madrid, Spain.

Miguel, C. 2001. Estudio de la podredumbre del cuello y frutos de calabaza causada por Fusarium solani (Mart.) Sacc. f. sp. cucurbitae W.C. Snyder \& H.N. Hans raza 1. PhD dissertation. Universidad Politecnica de Valencia, Valencia, Spain.

Nalim, F. A., Samuels, G. J., Wijesundera, R. L., and Geiser, D. M. 2011. New species from the Fusarium solani species complex derived from perithecia and soil in the Old World tropics. Mycologia 103:1302-1330.

Nelson, P. E., Dignani, M. C., and Anaissie, E. J. 1994. Taxonomy, biology, and clinical aspects of Fusarium species. Clin. Microbiol. Rev. 7:479-504.

Nirenberg, H. I. 1976. Untersuchungen über die morphologishe differenrierung in der Fusarium Sektion Liseola. Mitteilungen der Biologischen Bundesanstalt für Land- und Forstwirtschaft. 169:1-117.

O'Donnell, K. 2000. Molecular phylogeny of the Nectria haematococca-Fusarium solani species complex. Mycologia 92:919-938.

O'Donnell, K., Sutton, D. A., Fothergill, A., McCarthy, D., Rinaldi, M. G., Brandt, M. E., Zhang, N., and Geiser, D. M. 2008. Molecular phylogenetic diversity, multilocus haplotype nomenclature, and in vitro antifungal resistance within the Fusarium solani species complex. J. Clin. Microbiol. 46:2477-2490. 
Paternotte, S. J. 1987. Pathogenicity of Fusarium solani f. sp. cucurbitae race 1 to courgette. Neth. J. Plant Pathol. 93:245-252.

Pérez-Hernández, A., Porcel-Rodríguez, E., and Gómez-Vázquez, J. 2017. Survival of Fusarium solani f. sp. cucurbitae and fungicide application, soil solarization, and biosolarization for control of crown and foot rot of Zucchini Squash. Plant Dis. 101:1507-1514.

Porcel, E. 2013. Caracterización morfológica y patogénica de aislados de Fusarium solani f. sp. cucurbitae. Final degree project. Universidad de Almería, Almería, Spain.

Rambaut, A. 2013. FigTree. http://tree.bio.ed.ac.uk/software/figtree/

Rapilly, F. 1968. Les techniques de mycologie en pathologie vegetale. Ann. Epiphyt. 19: 102.

Reeb, V., Lutzoni, F., and Roux, C. 2004. Contribution of RPB2 to multilocus phylogenetic studies of the euascomycetes (Pezizomycotina, Fungi) with special emphasis on the lichen-forming Acarosporaceae and evolution of polyspory. Mol. Phylogenet. Evol. 32:1036-1060.

Rossman, A. Y., and Palm-Hernández, M. E. 2008. Systematics of plant pathogenic fungi: Why it matters. Plant Dis. 92:1376-1386.

Sandoval-Denis, M., Lombard, L., and Crous, P. W. 2019. Back to the roots: A reappraisal of Neocosmospora. Persoonia 43:90-185.

Schroers, H. J., Samuels, G. J., Zhang, N., Short, D. P. G., Juba, J., and Geiser, D. M. 2016. Epitypification of Fusisporium (Fusarium) solani and its assignment to a common phylogenetic species in the Fusarium solani species complex. Mycologia 108:806-819.

Short, D. P. G., O’Donnell, K., Thrane, U., Nielsen, K. F., Zhang, N., Juba, J. H., and Geiser, D. M. 2013. Phylogenetic relationships among members of the Fusarium solani species complex in human infections and the descriptions of $F$. keratoplasticum sp. nov. and F. petroliphilum stat. nov. Fungal Genet. Biol. 53:59-70.
Short, D. P. G., O’Donnell, K., Zhang, N., Juba, J. H., and Geiser, D. M. 2011 Widespread occurence of human pathogenic types of the fungus Fusarium detected in plumbing drains. J. Clin. Microbiol. 49:4264-4272.

Šišić, A., Baćanović-Šišić, J., Al-Hatmi, A. M. S., Karlovsky, P., Ahmed, S. A. Maier, W., de Hoog, G. S., and Finckh, M. R. 2018. The 'forma specialis' issue in Fusarium: A case study in Fusarium solani f. sp. pisi. Sci. Rep. 8:1252.

Snyder, W. C., and Hansen, H. N. 1941. The species concept in Fusarium with reference to section Martiella. Am. J. Bot. 28:738-742.

Summerell, B. A. 2019. Resolving Fusarium: Current status of the genus. Annu. Rev. Phytopathol. 57:323-339.

Swofford, D. L. 2002. PAUP*. Phylogenetic Analysis Using Parsimony (*and Other Methods). Version 4. Sinauer Associates, Sunderland, MA.

Tousson, T. A., and Snyder, W. C. 1961. The pathogenicity, distribution, and control of two races of Fusarium (Hypomyces) solani f. sp. cucurbitae. Phytopathology 51:17-22.

Wang, H., Xiao, M., Kong, F., Chen, S., Dou, H.-T., Sorrell, T., Li, R.-Y., and Xu, Y.-C. 2011. Accurate and practical identification of 20 Fusarium species by seven-locus sequence analysis and reverse line blot hybridization, and an in vitro antifungal susceptibility study. J. Clin. Microbiol. 49: 1890-1898.

Westerlund, F. V. J., Campbell, R. N., and Kimble, K. A. 1974. Fungal root rots and wilt of chickpea in California. Phytopathology 64:432-436.

Woudenberg, J. H., Groenewald, J. Z., Binder, M., and Crous, P. W. 2013. Alternaria redefined. Stud. Mycol. 75:171-212.

Zhang, N., O'Donnell, K., Sutton, D. A., Nalim, F. A., Summerbell, R. C., Padhye, A. A., and Geiser, D. M. 2006. Members of the Fusarium solani species complex that cause infections in both humans and plants are common in the environment. J. Clin. Microbiol. 44:2186-2190. 